Reports

1976

\title{
Tidal wetland plants of Virginia
}

Gene M. Silberhorn

Virginia Institute of Marine Science

Follow this and additional works at: https://scholarworks.wm.edu/reports

Part of the Botany Commons

\section{Recommended Citation}

Silberhorn, G. M. (1976) Tidal wetland plants of Virginia. Educational series; no. 19. Virginia Institute of Marine Science, William \& Mary. https://doi.org/10.21220/V5QT86

This Report is brought to you for free and open access by W\&M ScholarWorks. It has been accepted for inclusion in Reports by an authorized administrator of W\&M ScholarWorks. For more information, please contact scholarworks@wm.edu. 


\title{
TIDAL WETLAND PLANTS OF VIRGINIA
}

\author{
Gene M. Silberhorn
}

Illustrations By

Mary Warinner

April, 1976

Educational Series Number 19 of the

VIRGINIA INSTITUTE OF MARINE SCIENCE

Gloucester Point, Virginia 23062

Dr. William J. Hargis, Jr.,

Director 


\section{PREFACE}

This field book was written for those who want to know more about the common tidal wetland plants in Virginia and adjacent coastal states. Extensive field work has shown that these species are commonly found in saltwater, brackish water and freshwater marshes and swamps.

The text is presented in a non-technical vein. However, some of the more important and interesting plant characteristics that need to be explained are done so in basic botanical terms. For this reason a glossary is included for the reader's convenience.

A descriptive key is provided in order to facilitate the identification of species contained in this book. So that the description and illustration can be located quickly, the page number is given along with the common name within the key.

The description of the individual species and/or closely related species is found associated with its illustration. The description includes the general distinguishing characteristics of the plant, its habitat, and its importance to the environment.

One of the most important features of this publication is the fine drawings done by Mary Warinner. They were drawn primarily from live specimens collected from various Virginia marshes. Most of the species are depicted during the flowering period. 


\section{ACKNOWLEDGEMENTS}

The publication and distribution of this book has been partially provided by the National Sea Grant Program through a grant to the Virginia Institute of Marine Science (04-5-158-49) and by the Coastal Plains Center for Marine Development Services, through their Cooperative Projects Program.

The author wishes to thank Dr. William J. Hargis, Jr., Dr. Michael E. Bender, Mr. Kenneth Moore, Mr. Thomas Barnard, Jr., and Col. George Dawes for their constructive criticism and suggestions which have assisted in the development of this publication.

Thanks also to $\mathrm{Mr}$. Carl Hershner for information regarding fish populations in small marshes.

Sincerest appreciation is offered to Mr. Russell Bradley and Mr. Fred Biggs for preparing the manuscript for publication.

Finally, I thank Mrs. Beth Marshall, Mrs. Rhonda Pavne, Miss Christine Plummer and Mrs. Carole Knox for typing the various drafts and final manuscript. 


\section{TABLE OF CONTENTS}

Introduction $\ldots \ldots \ldots \ldots \ldots \ldots \ldots \ldots \ldots \ldots \ldots \ldots \ldots \ldots$

A Key to Common Tidal Wetland Flora $\ldots \ldots \ldots \ldots \ldots \ldots \ldots$

Glossary ............................. 9

List of Plant Illustrations

Saltmarsh Cordgrass Spartina alterniflora . . . . . . . . . . . . 12

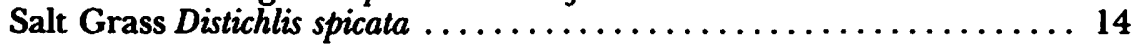

Saltmeadow Hay Spartina patens . . . . . . . . . . . . . 16

Black Needlerush Juncus roemerianus ................. 18

Saltwort, Glasswort Salicornia bigelovii .................. 20

Saltwort, Glasswort Salicornia virginica . . . . . . . . . . . . . . . 20

Sea Lavender Limonium nashii .................... 22

Sea Oxeye Borrichia frutescens . . . . . . . . . . . . . 24

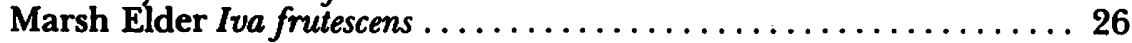

Groundsel Tree Baccharis halimifolia ................ 28

Saltmarsh Fleabane Pluchea purpurascens ............... 30

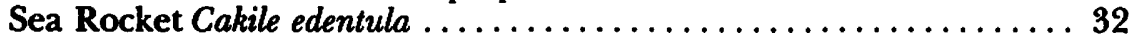

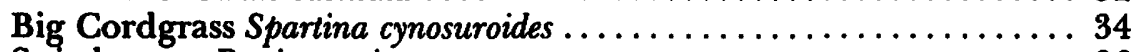

Switch-grass Panicum virgatum $\ldots \ldots \ldots \ldots \ldots \ldots \ldots \ldots \ldots \ldots \ldots$

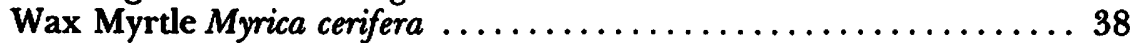

Reed Grass Phragmites australis $\ldots \ldots \ldots \ldots \ldots \ldots \ldots \ldots \ldots \ldots$

Waterhemp Amaranthus canabinus . . . . . . . . . . . . . . . 42

American Threesquare Scirpus americanus . . . . . . . . . . . 44

Olney Threesquare Scirpus olneyi ................... 44

Saltmarsh Bulrush Scirpus robustus ...................46

Marsh Hibiscus Hibiscus moscheutos . . . . . . . . . . . . . . 48

Narrow-leaved Cattail Typha angustifolia . . . . . . . . . . . 50

Common Cattail Typha latifolia .................. 50

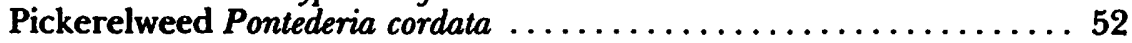

Arrow Arum Peltandra virginica $\ldots \ldots \ldots \ldots \ldots \ldots \ldots \ldots \ldots \ldots$

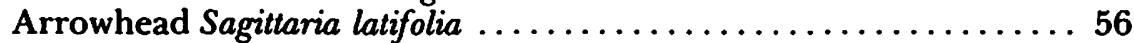

Yellow Pond Lily Nuphar luteum ................... 58

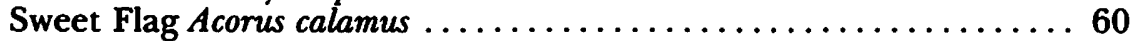

Northern Wild Rice Zizania aquatica ............... 62

Rice Cutgrass Leersia oryzoides . . . . . . . . . . . . . . 64

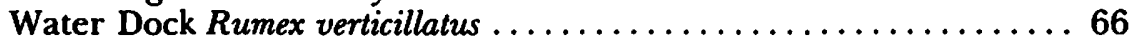

Smartweed Polygonum punctatus . . . . . . . . . . . . . 68

Sagittate Tearthumb Polygonum sagittatum . . . . . . . . . 70

Hastate Tearthumb Polygonum arifolium . . . . . . . . . . . 70

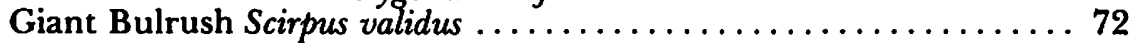

Squarestem Spikerush Eleocharis quadrangulata ............ 74

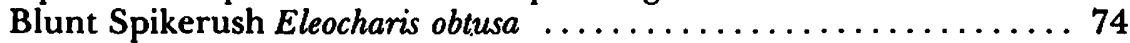

Dwarf Spikerush Eleocharis parvula ................. 74

Royal Fern Osmunda regalis var. spectabilis . . . . . . . . . . 76

Beggar-ticks Bidens coronata ..................... 78

Button Bush Cephalanthus occidentalis . . . . . . . . . . . . . 80

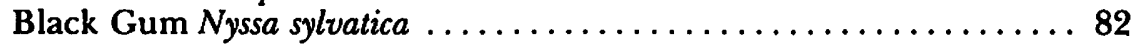

Bald Cypress Taxodium distchum .................. 84 


\section{INTRODUCTION}

For many years wetlands have been maligned by man for various reasons. They have been condemned as breeding grounds for mosquitos, snakes and other creatures, real or imagined. Square miles of saltmarshes on the East Coast have stood in the way of seaside developments. They are now covered by fill and have been transformed into high-rise structures, shopping centers, parking lots and other man-made veneer.

Other marshes have had their natural, meandering channels straightened to facilitate waterfront utilization. In the process of dredging, the natural bottoms and marsh peat have been churned into a soup-like suspension that, more often than not, has been spilled upon the marsh surface and contained by dikes. After the water has been drained off, the sediment remains. After a year or two, what was once part of the marsh ecosystem has become an arid landscape, devoid of vegetation except for a few weedy invaders.

Many of the great saltmarshes along the Atlantic Coast have been modified by extensive systems of mosquito ditches that appear from the air as vast lattice patterns. Yet many stagnant ponds, which are the real breeding areas for mosquitos, lie placid and untouched between the ineffective ditches. Since the late 1930's many square miles of productive Saltmarsh Cordgrass marshes, which produce very few mosquitos, have been seriously altered. Because of ditching, these marshes are of far less value to waterfowl and the marine food web.

Prompted by the results of research by marine biologists and marsh ecologists in the last ten or fifteen years, many seaboard states and the federal government have passed legislation to protect productive tidal wetland ecosystems. In the past it has been generally known that marshes are an important habitat and food source for waterfowl. Only in recent years, however, has it been substantially determined that marshes act as an important source of organic material for adjacent estuaries. About one half of the plant material produced by a saltmarsh is flushed into the estuary. The stems and leaves eventually fragment into tiny particles (detritus) through decay by action of bacteria and fungi. Small crustaceans (copepods and amphipods) feed upon the bacteria and fungi, and juvenile fishes consume the crustaceans in large numbers. Crabs, oysters and clams consume the organic material directly. Tidal marshes are 
therefore extremely valuable to marine life. Marshes also absorb flood waters, trap sediments, buffer shoreline erosion, and improve water quality by assimilating nutrients originating from agricultural cropland runoff and sewage outfalls.

In 1972, the Virginia Wetlands Act was passed. As of July 1st of that year, a permit has been required before any activity is performed in the Commonwealth that may affect tidal wetlands. As a result of this landmark legislation, the amount of wetland destruction has been greatly reduced from a predicted loss of 400 acres per year (1970's) ${ }^{1}$ to less than 20 acres per year since 1972. Organizations having an active role in the success of the Act are the Virginia Marine Resources Commission, the principal enforcement agency; the local wetland boards, the local authority, and the Virginia Institute of Marine Science, the scientific and technical advisory agency of the Act.

For management purposes, the wetlands are defined in the Act as "all land lying between and contiguous to mean low water and an elevation above mean low water equal to the factor 1.5 times the mean tide range ..." and upon which grow one or more specific types of vegetation (Virginia Code, 62.1-13.2 f). At least forty different species of marsh plants are listed. These species are the most common plants found in tidal saltwater, brackish water and freshwater wetlands. These plants are described and illustrated in this publication.

Virginia is well endowed with tidal wetlands. The largest wetland systems are found in the two Eastern Shore Counties (Accomack and Northampton) with approximately 126,000 acres on the Atlantic and Chesapeake Bay shorelines. Accomack County alone has over 76,000 acres of salt and brackish water marshes. The most extensive wetland acreage are the vast saltmarshes situated behind the Barrier Islands. As of this writing, approximately $80 \%$ of the Barrier Islands on Virginia's Eastern Shore are owned by the Nature Conservancy, an organization dedicated to the preservation of natural areas. These islands are one of the last remaining undeveloped coastal marine systems on the Atlantic Seaboard.

The most extensive brackish water marshes in the Commonwealth are found on the Chesapeake Bay side of Eastern Shore, mostly concentrated in Accomack County. Here are found a diversity of grasses, sedges, rushes, saltbushes and other types of marsh vegetation.

Along the Pamunkey, Mattaponi, James and Rappahannock rivers are some of the largest tidal freshwater wetlands on the East Coast. These marshes support a highly diverse vegetation. At the height of the growing season (July through September) it is possible to find over fifty species of plants on one acre of undisturbed marsh. Here grow the succulent Arrow Arum, Pickerel Weed, Arrowhead and Yellow Pond Lily; the dense stands of Big Cordgrass and Wild Rice and the colorful flowers of Marsh 
Hibiscus, Beggar's Ticks, Cardinal Flower, Swamp Milkweed and others. In the fall of the year, large flocks of ducks and geese rest and feed here during migration. Numerous birds such as rails make their permanent home here. Tidal freshwater marshes are very important spawning and nursery areas for various species of finfish, particularly shad and herring.

In addition to these vast marsh systems, there are thousands of small marshes of one acre or less that are valuable for various reasons. Fringing marshes protect the shoreline. Pocket marshes, at the upper ends of tidal creeks, filter out sediments from upland runoffs. Small cove marshes, fringed with Saltmarsh Cordgrass, support large numbers of juvenile fish. In a VIMS study for example, it was found that an estimated 20,000 young spot utilized a small cove marsh during just one tidal cycle.

It is estimated that there are approximately 280,000 acres of vegetated tidal wetlands in the Commonwealth. This area represents only one half of one percent of the total land area in Virginia, and yet the value of these natural systems can not be overestimated. Approximately $95 \%$ of the commercial and sport fishes in Virginia are dependent upon the existence of these marshes.

Science may eventually be able to determine the numerous contributions of tidal wetlands to the coastal ecosystem and from this information estimate their value to man.

However, evaluating tidal wetlands on the basis of esthetics presents a very different set of circumstances. The massive prairie-like appearance of the saltmarshes of the Eastern Shore and the lush, tropical-like vegetation of the freshwater marshes of the Mattaponi and Pamunkey rivers have a particular gestalt beauty that is indescribable. Many people feel that esthetics is reason enough for their conservation.

'Settle, Fairfax, 1969. Survey and analyses of changes effected by man on tidal wetlands of Virginia. M.S. Thesis, VPI \& SU, Blacksburg. 


\section{A KEY TO COMMON TIDAL WETLAND FLORA}

(as found in text)

A. Grasses or Grass-like plants: Grasses, Sedges, Rushes, Cattails, Sweet Flag

1. Plants 6 to 12 feet high $\ldots \ldots \ldots, \ldots \ldots \ldots \ldots \ldots \ldots$. 2

2. Leaves long tapering, with rough edges .......... 3

3. Inflorescence, coarsely branched, seeds on all branches .. Big Cordgrass p. 34

3. Inflorescence delicate, copiously branched, seeds (rice grains) only on upper branches .........Wild Rice p. 62

2. Leaves without rough edges or leaves absent $\ldots \ldots \ldots \ldots, 4$

4. Leaves absent, stem round, terminal flower cluster ...... Giant Bulrush p. 72

4. Leaves with smooth edges, inflorescence a feathery panicle ......................Reed Grass p. 40

1. Plants 1 inch to 6 feet high ................... 4

4. Stems (culms) appearing leafless or few leaves ....... 5

4. Stems with many conspicuous leaves ............ 9

5. Stems round or square in cross section ............ 6

5. Stems triangular, leafless at maturity. Threesquares p. 44

6. Stems square in cross-section Square-stem Spikerush p. 74

6. Stems round in cross-section ................. 7

7. Inflorescence extending laterally from stem, not terminal

Black Needlerush p. 18

7. Inflorescence, terminal or appearing so .......... 8

8. Plant 4 to 8 feet high ............Giant Bulrush p. 72

8. Plant 1 inch to 3 feet high ............Spikerushes p. 74

9. Stems basically round in cross section ............. 10

10. Inflorescence a cylinder-shaped, compacted seed head (wiener-on-a-stick) . . . . . . . . . . . . 50 
10. Inflorescence, branched, in loose clusters or panicled ...

12. Short, wiry grasses, (1 to 3 feet) forming meadows or

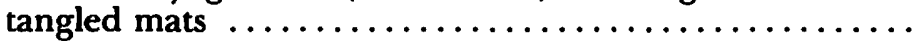

13. Leaves with cutting edges, tangled mats, freshwater marshes ..................... Rice Cut Grass p. 64

13. Leaves smooth, forming meadows, salt and brackish water

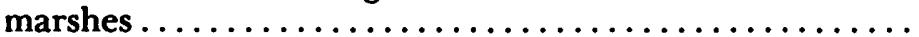

14. Infloresence, branched, leaves rolled inward

Saltmeadow Hay p. 16

14. Inflorescence, loosely clustered heads, leaves in one plane Salt Grass p. 14

12. Tall grasses (usually 3 to 6 feet) $\ldots \ldots \ldots \ldots \ldots \ldots \ldots, 15$

15. Inflorescence, delicately branched panicle, high marsh grass ....................... Switch Grass p. 36

15. Inflorescence, branched but appearing as a single head, intertidal area ............. Saltmarsh Cordgrass p. 12

9. Stems triangular or angular in cross section ...........

11. Seedhead clustered, leafy stems .Saltmarsh Bulrush p. 46

11. Seedhead elongated, cylindrical, leaves basal ..........

Sweet Flag p. 60

B. Non-flowering Plants and Plants with Minute, Inconspicuous Flowers

1. Plant with fern-like leaves, freshwater marshes .........

Royal Fern p. 76

1. Plants without leaves, stems succulent

Saltworts, Glassworts p. 20

C. Woody Plants: Shrubs and Trees

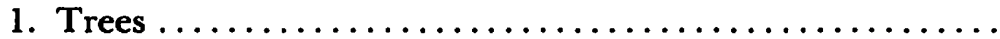

2. Needle-like leaves, deciduous falling in autumn ........

Bald Cypress p. 84

2. Broad leaves, deciduous .............The Gums p. 82

1. Shrubs $\ldots \ldots \ldots \ldots \ldots \ldots \ldots \ldots \ldots \ldots \ldots \ldots \ldots \ldots \ldots \ldots, 3$

3. Leaves evergreen, dark green, blue waxy fruit

Wax Myrtle p. 38

3. Leaves deciduous, without blue fruit 
4. Leaves opposite or whorls of 3 on stem .......... 5

5. Shrubs with globe-like inflorescence and/or fruiting head, freshwater marshes ...............Button Bush p. 80

5. Shrubs without globe-like inflorescence, salt or brackish

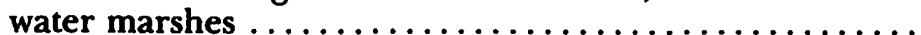

6. Low shrub (up to 3 feet), daisy-like yellow flower ....... Sea Oxeye p. 24

6. Tall shrub (up to 15 feet) greenish inflorescence ........ Marsh Elder p. 26

4. Leaves alternate on stem, beige-yellow flowers .........

Groundsel tree p. 28

D. Plants with Conspicuous Flowers or Pod-like inflorescences

1. Leaves large, blade 8 inches to 3 feet long, emergent fresh

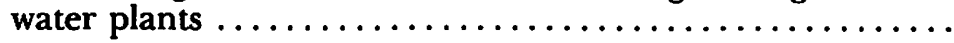

2. Leaves arrowhead shaped, heart-shaped, or lance-shaped, blades vertically oriented $\ldots \ldots \ldots \ldots \ldots \ldots \ldots \ldots$.

3. Blades arrowhead-shaped or lance-shaped, flowers white

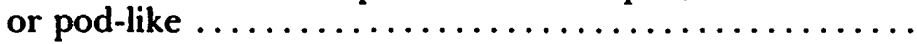

4. Inflorescence with white flowers, arrowhead or lanceshaped leaves ...................Arrowhead p. 56

4. Inflorescence pod-like, with fleshy flowers surrounded by a leaf-like jacket ................. Arrow Arrum p. 54

3. Blades heartshaped or somewhat triangular, blue flowers ..................... Pickerel Weed p. 52

2. Leaves round to slightly heart shaped horizontally oriented, often floating, yellow flowers Yellow Pond Lily p. 58

1. Leaves small, blades 1 inch to 8 inches long, various habitats

5. Plants with small succulent leaves ..................

6. Leaves alternate, flowers pink or whitishSea Rocket p. 32

6. Leaves opposite, flowers yellow (low shrub) Sea Oxeye p. 24

5. Plants without succulent leaves $\ldots \ldots \ldots \ldots \ldots \ldots \ldots, 7$

7. Plants with large showy flowers, ( 2 to 7 inches), color yellow,

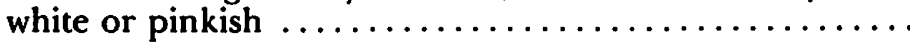

8. Flowers yellow, freshwater marsh ...Beggar's Ticks p. 78

8. Flowers white or pinkish ..........Marsh Hibiscus p. 48 
Rhizome: An underground stem, usually elongated and horizontal and producing aerial shoots.

Sagittate: Referring to the shape of the basal lobes of a leaf. Twin sharply pointed lobes pointing downward.

Spadix: A spike of fleshy flowers such as found in Arrow Arum and Sweet Flag.

Spathe: A large, leaf-like bract enclosing or surrounding an inflorescence. Usually the inflorescence is a spadix.

Spinnules: Minute sharp spines, usually found on the leaf margin of some grasses.

Staminate: Flowers having stamens only, (the male reproductive part of the flower). Pistils (female) absent or non-functional.

Stigmas: That part of the pistil (female reproductive organ) that receives the pollen. In many cases, such as in Button Bush, they resemble an elongated filament.

Tufts: Growing in dense clumps such as found in many grasses, sedges and rushes. 


\section{PLANT ILLUSTRATIONS}




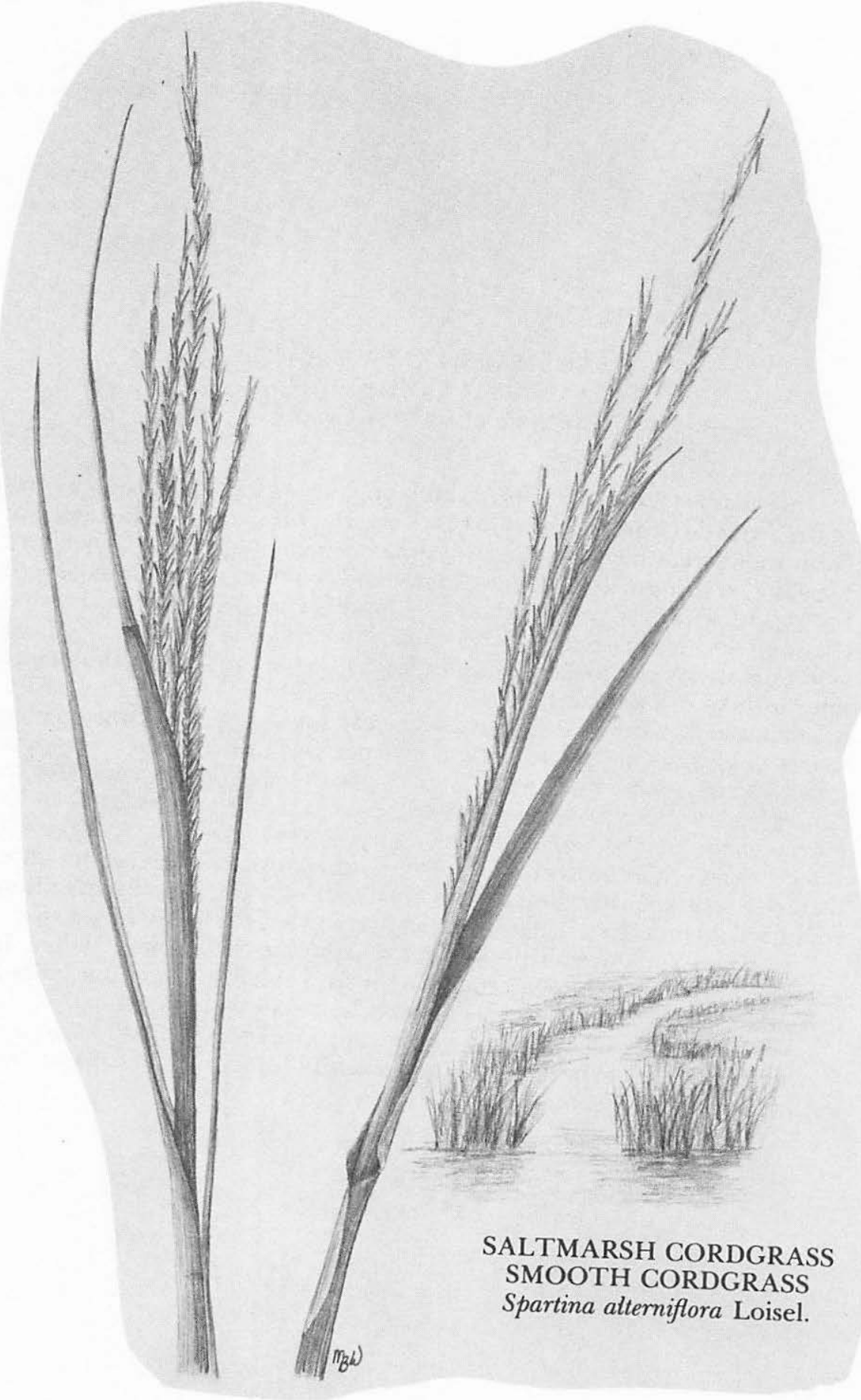




\section{SALTMARSH CORDGRASS SMOOTH CORDGRASS Spartina alterniflora Loisel.}

Saltmarsh Cordgrass is the dominant plant species of the saltmarshes of the Atlantic Coast. It grows in the intertidal zone, ranging in elevation from about mean sea level to approximately mean high water. There are usually two recognized forms of Spartina alterniflora; the tall form (4 to 6 feet high) which is restricted to the margins of creeks, guts, natural channels and other areas that are subject to daily tidal flooding, and the short form which occupies the higher levels of the marsh near the upper limit of tidal influence.

Saltmarsh Cordgrass is an extremely hardy plant, being able to tolerate saltwater inundation 12 hours per day and the fury of storm lashed waters. No other species of higher plants can compete with Cordgrass in this harsh environment except at the upper limits of its range (mean high water). Because of it's enduring qualities, Cordgrass is valued as an inhibitor to erosion. Waterfront property owners who have planted $S$. alterniflora within the intertidal zone of their shoreline are often rewarded, in time, by a fringing marsh that acts as a buffer to wave action.

Cordgrass is the most important marsh plant of saline marshes. It produces vast amounts of vegetative material annually. About one half of this material (detritus) is flushed from the marsh by tidal action.

Eventually, while floating in the surrounding waters, it decays through the action of bacteria and fungi and becomes a significant part of the estuarine food web. 


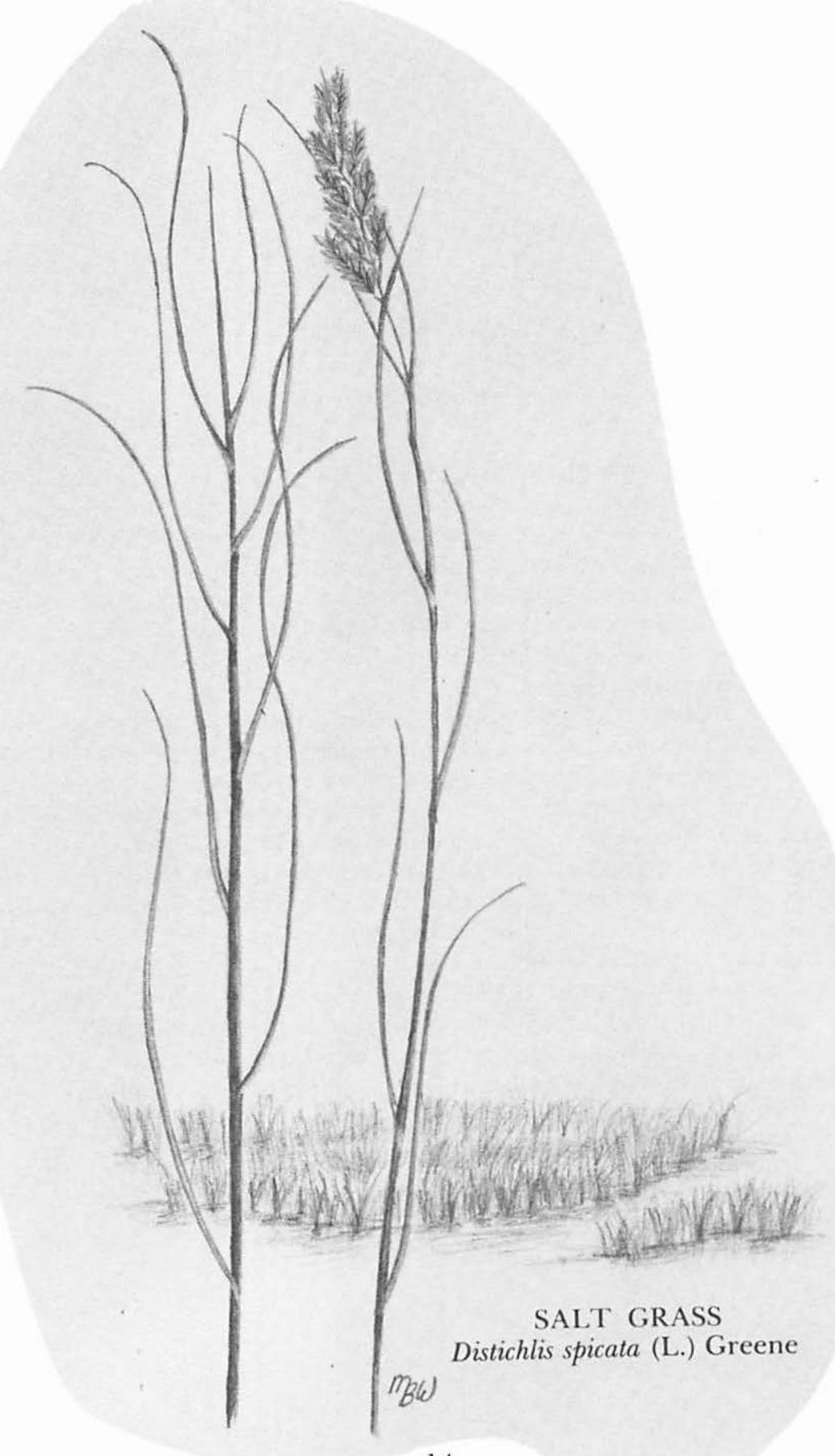




\section{SALT GRASS}

Distichlis spicata (L.) Greene

Salt Grass is one of the short, wiry grasses which dominate the meadow community in higher parts of salt or brackish water marshes. In these areas it is often associated with Saltmeadow Hay, Spartina patens. The leaves of Salt Grass are relatively short and somewhat trough-shaped and are arranged in one plane on the stem (opposite sides of the stem), especially in young vegetative forms. The plant resembles Saltmeadow Hay, however, the leaves of $S$. patens appear round and are arranged in several planes around the stem.

The infloresence of Salt Grass appears from August to September as a loosely compacted head, unlike the sparsely branched head of Saltmeadow Hay which blooms somewhat earlier. When in bloom (showy anthers of the male flower), Salt Grass meadows have a uniform whitish-green cast. In contrast, the earlier bloom of Saltmeadow Hay gives the meadow a rusty brown hue.

Salt Grass is usually found in the wetter, more saline parts of the meadow and has the ability to withstand higher concentrations of salt than Saltmeadow Hay. Salt Grass is often found in association with the short form of Saltmarsh Cordgrass, near or just above the mean high water line.

Salt Grass often invades sand overwash areas or dredge spoil sites that are occasionally washed by tides. Characteristically, young vegetative sprigs appear in a rope-like pattern, having originated from an underground stem, the rhizome. 


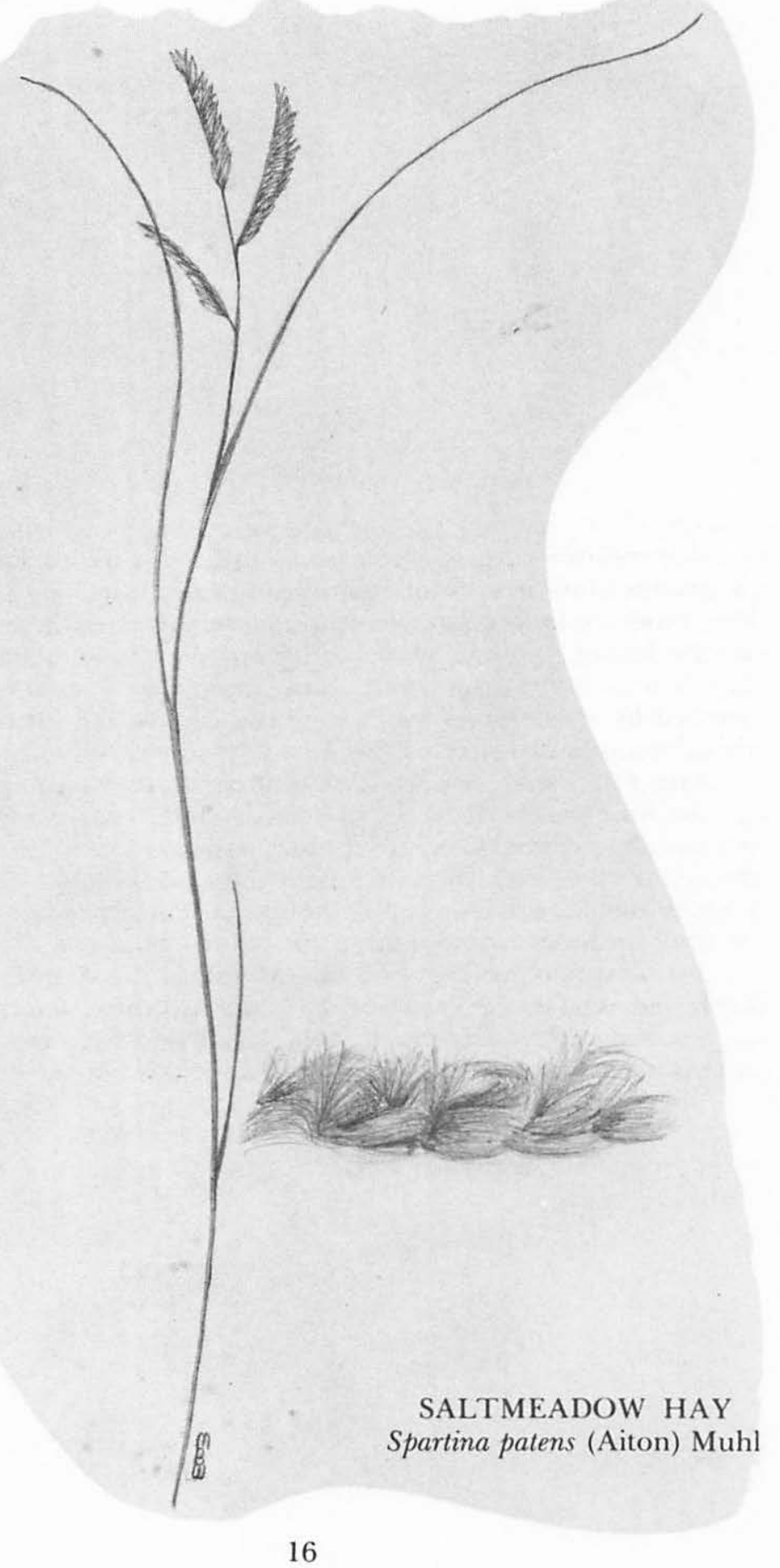




\section{SALTMEADOW HAY \\ Spartina patens (Aiton) Muhl}

Saltmeadow Hay is a fine, wiry grass usually appearing as dense, matted meadows in the higher parts of a salt or brackish water marsh. The long tapering leaves are rolled inward so that they appear round. The longest leaves are nearly one-half or two-thirds the length of the stem. The base of the stem is quite weak and has a tendency to bend when stressed by winds or occasional spring tides. When this happens individual stems intertwine and the overall effect is the characteristic cowlicks or swirls that often occur in large saltmarsh meadows.

In lower areas in the meadow where water accumulates during spring tides, Saltmeadow Hay is often associated with Saltgrass. Towards the upper margin of the marsh, Saltmeadow Hay is often found as a cover plant under Marsh Elder or Groundsel Tree. This grass also occurs on coastal foredunes where it has a tufted growth form.

In many marshes along the East Coast, Saltmeadow Hay is grazed or harvested as a forage crop for cattle. Saltmeadow Hay is mainly a coastal species, ranging from Maine to Texas although there are disjunct stands in saline marshes in New York and Michigan. 


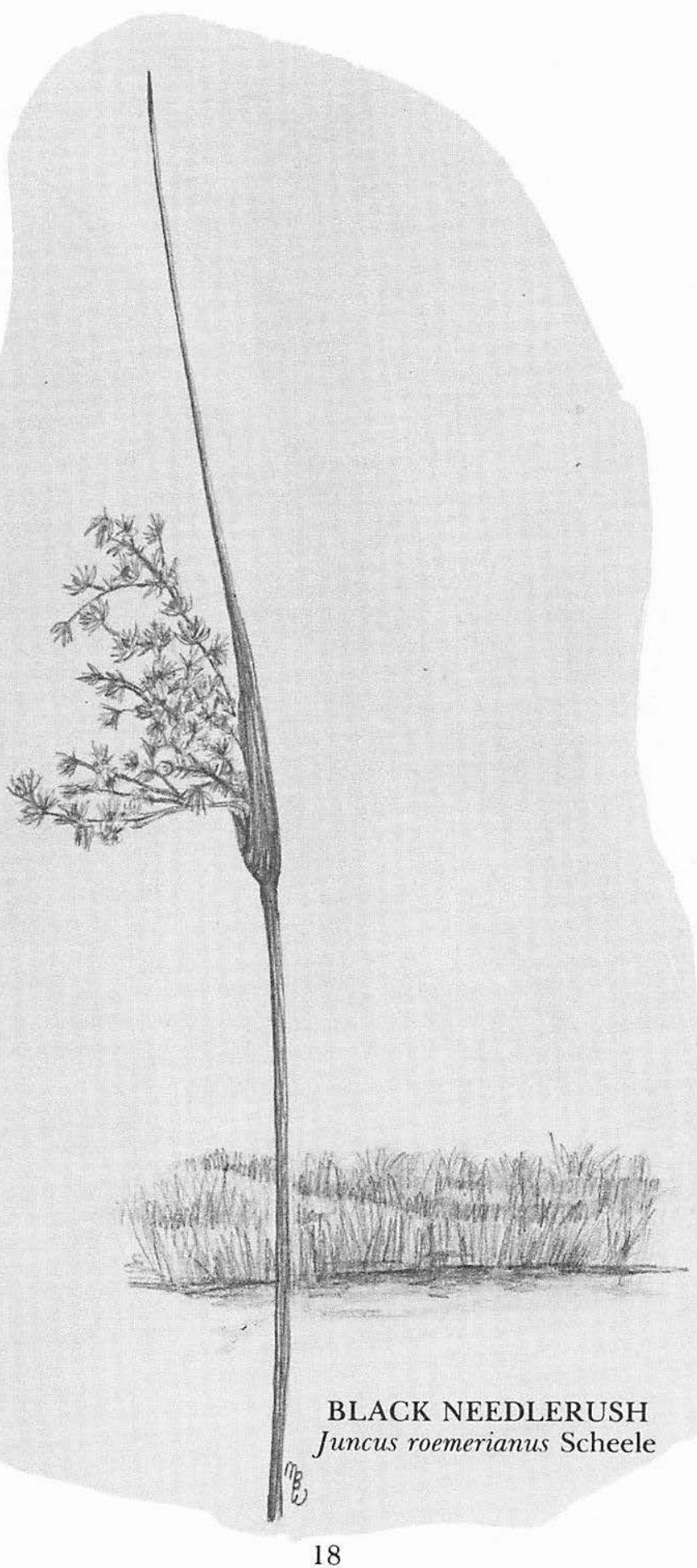




\section{BLACK NEEDLERUSH \\ Juncus roemerianus Scheele}

Black Needlerush is a very stiff, coarse and outwardly simple marsh rush, usually found growing in dense stands of nearly uniform heights. It is much darker green than the typical saline marsh grasses. The tip of the stem (actually a cylindrical leaf) has a noticeably sharp point from which its common name is derived.

Black Needlerush is usually found above the intertidal zone in brackish and saltwater marshes. The nearly black, coarse rhizomes form dense mats which are very resistant to erosion. Juncus roemerianus is most abundant throughout the south along the Atlantic Coastal plain and the Gulf Coast to Texas. In Virginia, the largest marshes dominated by this rush are found on the Chesapeake Bay side of the Eastern Shore (Delmarva Peninsula).

Another rush, Juncus gerardi (Black Grass or Black Rush), is occasionally seen in association with Saltmeadow Hay and Marsh Elder on Virginia's Eastern Shore; however it is never a major component of the coastal saltwater marshes this far south. This northern rush is easily distinguished from Black Needlerush in that it is much shorter and has a finer, more delicate appearance. 


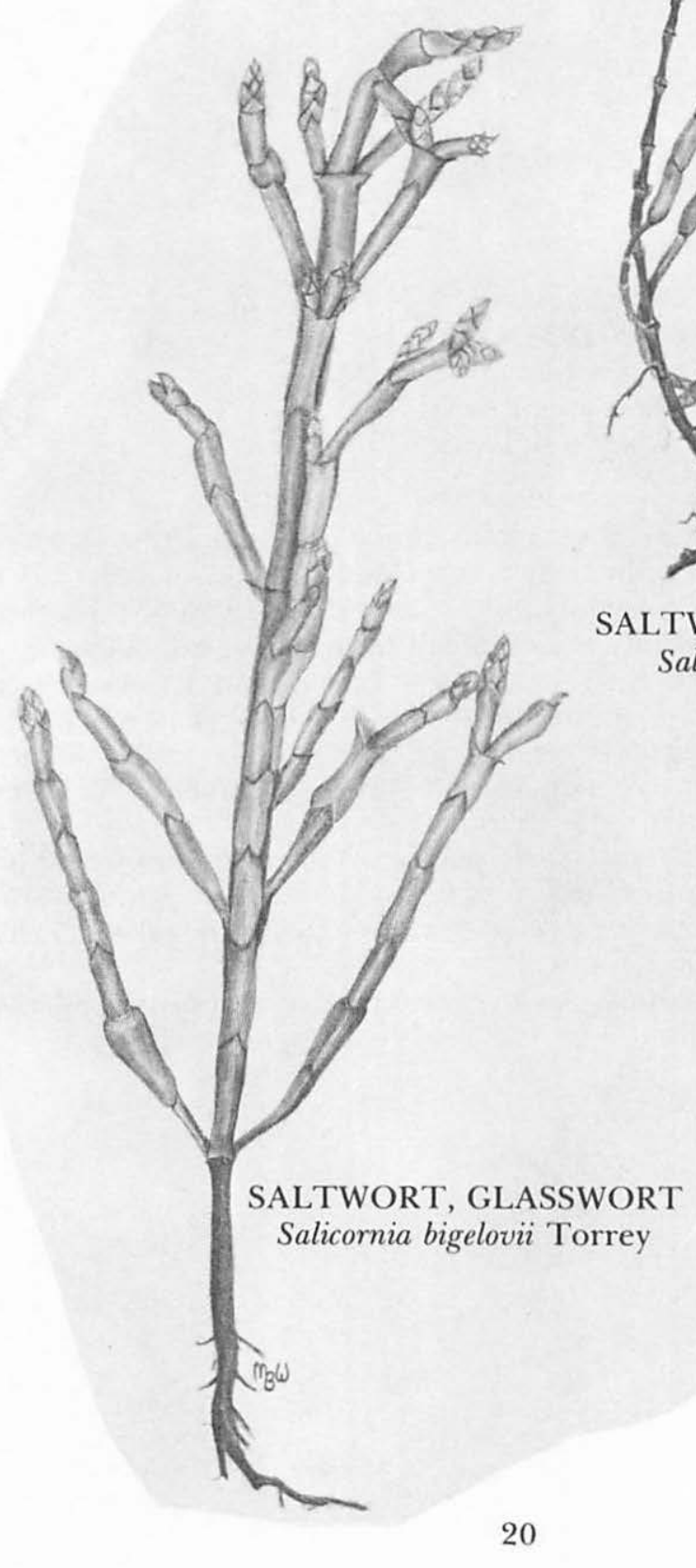


SALTWORT, GLASSWORT

Salicornia virginica $\mathrm{L}$. (illustrated)

Salicornia europaea $\mathbf{L}$.

Salicomia bigelovii Torrey (illustrated)

Some of the more unusual plants that are endemic in salt and brackish water marshes are the Saltworts or Glassworts. Resembling jaded twigs with thick, succulent terminal branches, these species of the genus Salicomia are flowering plants, essentially without leaves. The flowers are inconspicuous and occur on the terminal portions of the branches.

Two species of Salicomia, $S$. europaea and $S$. bigelovii are annuals, diffusely branched and fleshy. Salicomia virginica is perennial, with hard or woody prostrate stems, usually found in matted colonies. All three species commonly occur in the drier, sandy areas of the marsh. In Virginia's massive Eastern Shore salt marshes, Salicornia virginica is also found with the short form of Saltmarsh Cordgrass, Spartina alternifiora. $S$. europaea turns to deep pink or ruby red in autumn while the other species turn brown or yellowish.

The thick fleshy stems of all species can be pickled and preserved and are considered a delicacy. 


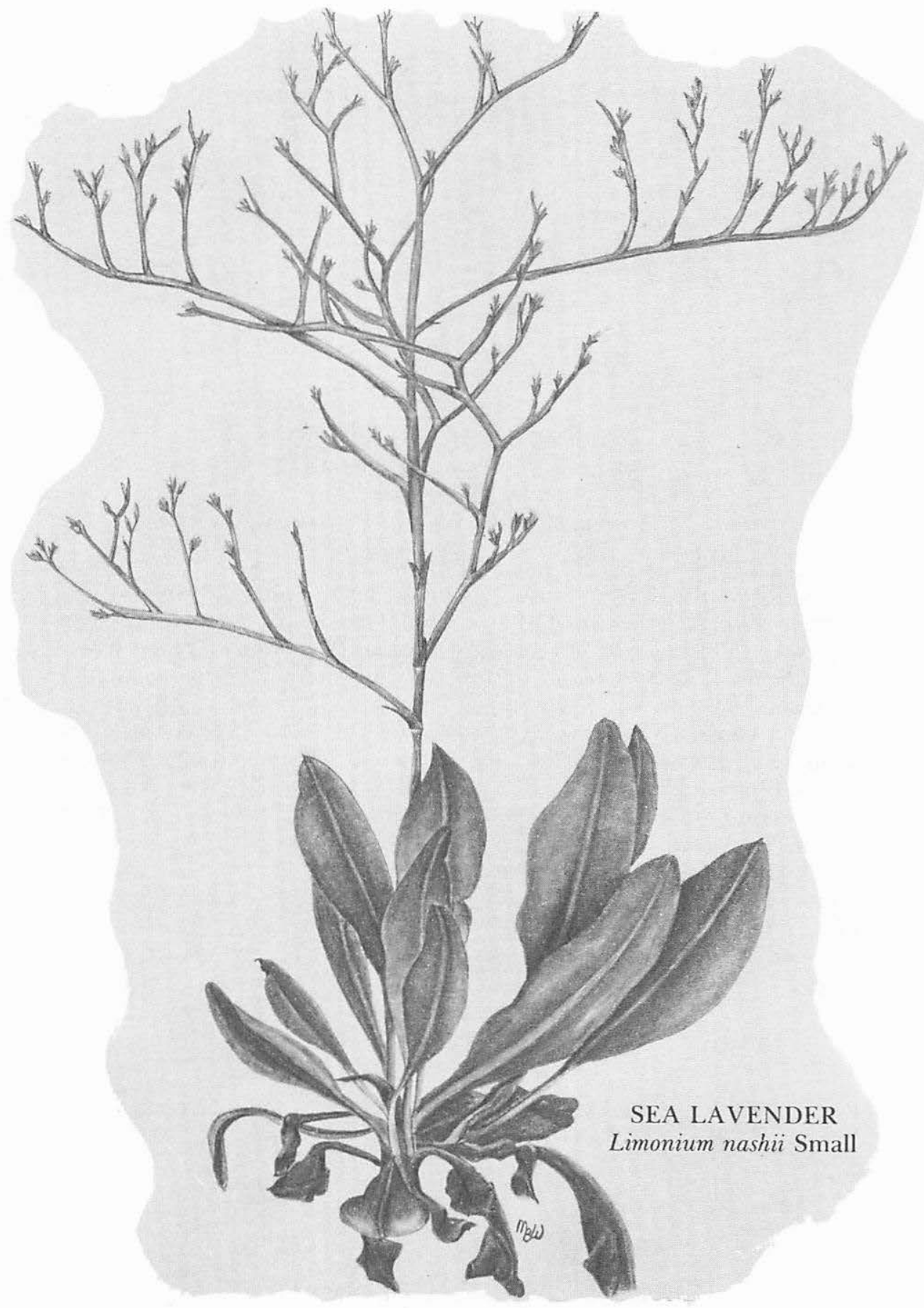


SEA LAVENDER

Limonium carolinianum (Walter) Britton

Limonium nashii Small (illustrated)

The Sea Lavenders are perennial herbs with basal rosettes of fleshy, leathery, smooth leaves and diffusely spreading infloresences (panicles) dotted with a multitude of tiny lavender or blue flowers. The panicles are prized for bouquets and dried arrangements. They are commonly found in salt or brackish water marshes but seldom are a dominant part of the marsh community.

The two different species of Sea Lavenders occuring along the Atlantic Coast are very similar in appearance. Only after close examination of the tiny blossoms can one tell the difference between the two.

Sea Lavenders bloom from July to October and the leaves remain until mid-winter. 


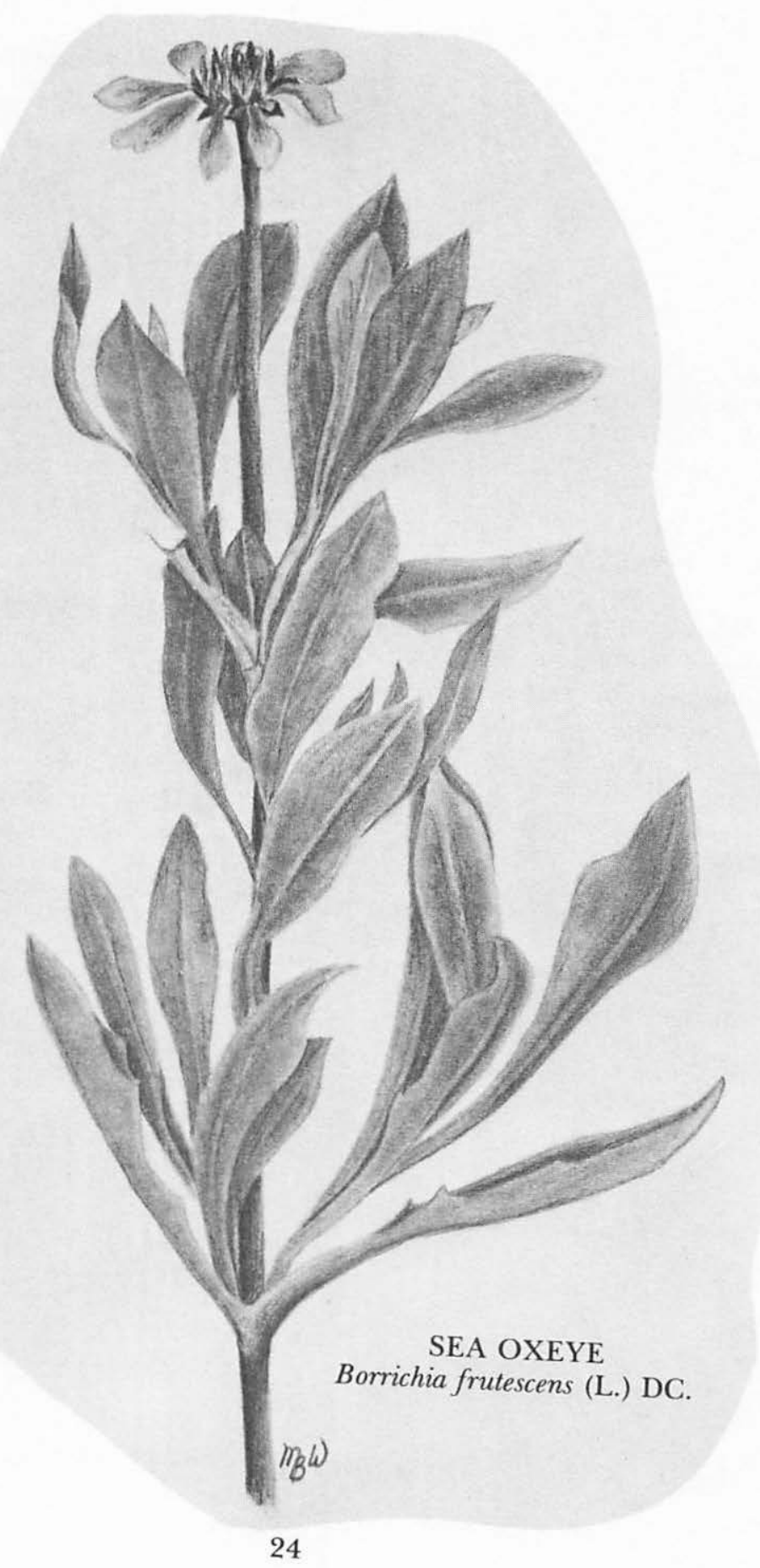




\section{SEA OXEYE \\ Borrichia frutescens (L.) DC.}

Flowering in summer, the yellow, composite blossoms of Sea Oxeye are the more striking flowers found in salt and brackish water marshes. This low shrub with thick, green leaves is nearly always found in dense colonies in the higher parts of the marsh. It is often associated with Saltmeadow Hay and frequently found on the fringes of saltbush communities.

Dark brown, burr-like seed heads appear in late autumn. However, the most common means of propagation is by underground rhizomes, resulting in the characteristic colonial populations.

Sea Oxeye is a coastal species endemic to saline marshes. It ranges from Virginia to Florida and along the Gulf Coast to Mexico. There are also disjunct populations in Bermuda. 


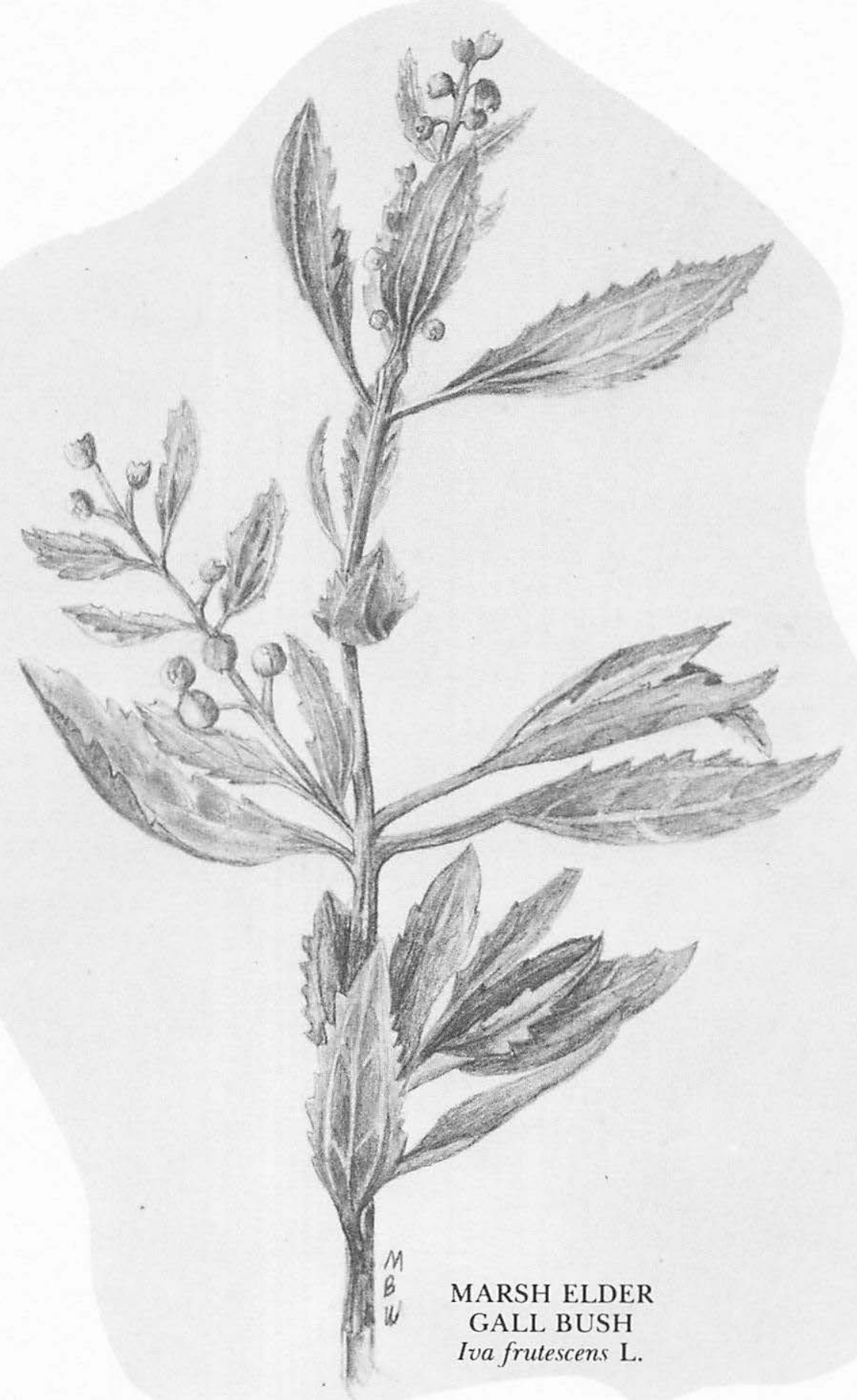




\section{MARSH ELDER \\ GALL BUSH \\ Iva frutescens $L$.}

Marsh Elder is found at the upland margins or on small hummocks in salt or brackish water marshes. It seldom grows over 10 feet tall and is therefore usually shorter than the other saltbush, Groundsel Tree, Baccharis halimifolia. Although the two shrubs are similar in general appearance, a closer look will note characteristic differences.

Marsh Elder has thicker leaves than Groundsel Tree and they are oppositely arranged on the stem. Groundsel Tree has thinner leaves that are alternately arranged. Also, the leaves of Marsh Elder are more distinctly toothed and the blades tend to taper towards both ends. Marsh Elder belongs to the composite family as do other plants such as daisies, thistles, dandelions and many marsh plants such as Groundsel Tree, Sea Oxeye and Beggar's Ticks. The chief characteristic of this family is that the flowers are usually diminutive and are compactly arranged in heads (composites). The flower head is surrounded by a series of tiny, green leaf-like appendages called an involucre. Many of the heads of this shrub are arranged on the terminal stems of the shrub and appear as green globular fruits.

Iva and Baccharis often occur together as the saltbush community at higher levels in the marsh and occasionally serve as nesting areas for herons (heronries) within the vast coastal saltmarshes of Virginia's Eastern Shore. 


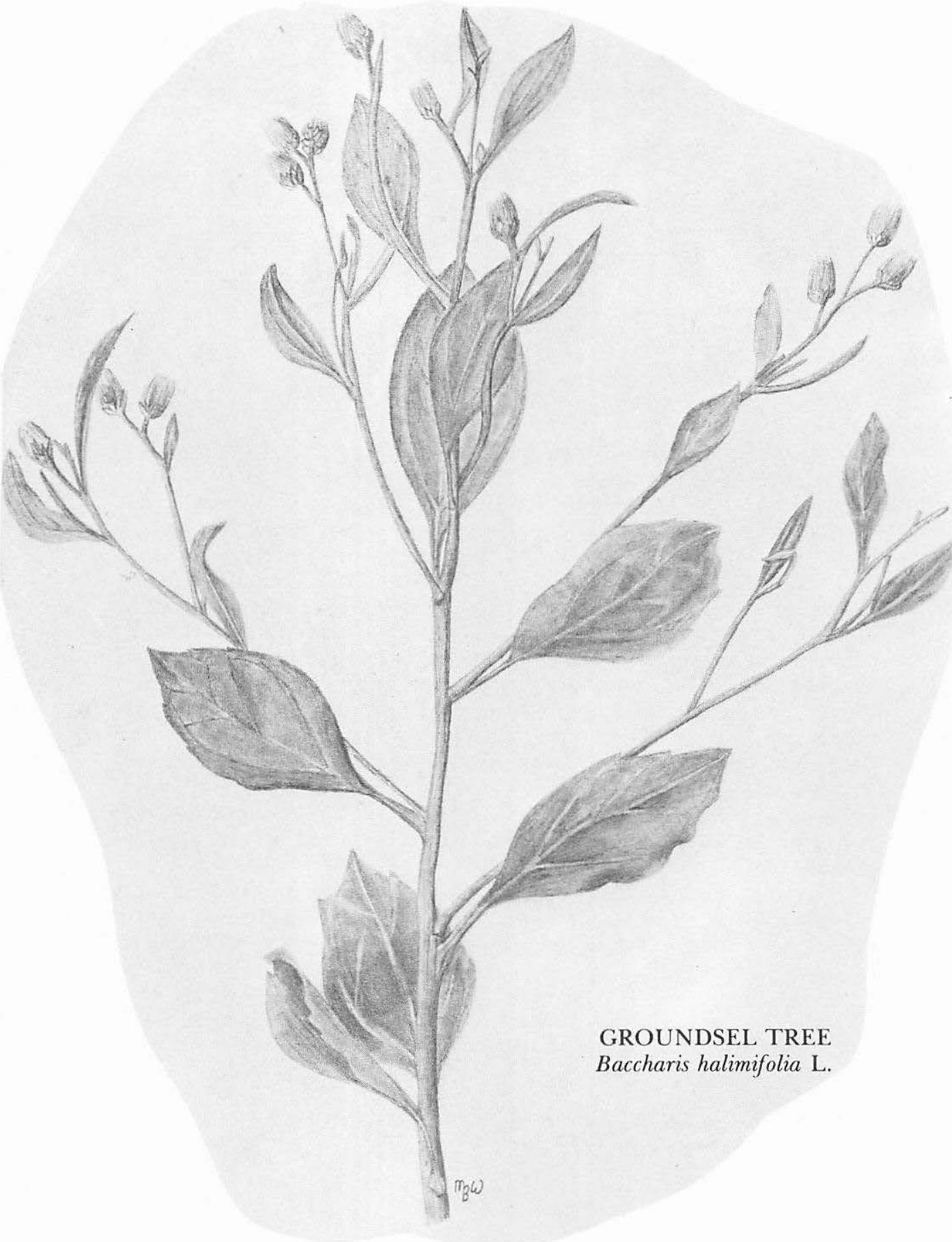




\section{GROUNDSEL TREE Baccharis halimifolia $\mathbf{L}$.}

. Groundsel Tree is a tall, robust shrub often associated with Marsh Elder, Iva frutescens, to form the saltbush community of salt and brackish marshes. Groundsel Tree has a number of common names in this region such as Silvering (because of its white seeds), Sea Myrtle and Consumption Weed to name a few. This shrub is dioecious, that is, an individual shrub may have either female (pistillate) or male (staminate) blossoms, but not both. In late August or September, the beige-yellow flower heads appear and by late September and continuing until early winter, the white bristles (pappus) on the seeds of the pistillate shrubs are prominent. Although Groundsel Tree is deciduous, the naked stems remain somewhat greenish throughout the winter. In contrast the bare branches of Marsh Elder have a whitish-gray appearance. The thin, alternate leaves distinguish Groundsel Tree from Marsh Elder which has thick opposite leaves.

Saltbushes are "collectors" of flotsam, such as timber, eel grass, Crab pot floats, and other debris left by flood waters.

Groundsel Tree is mainly a coastal species, ranging from Massachusetts to Florida and areas of the Gulf Coast. 


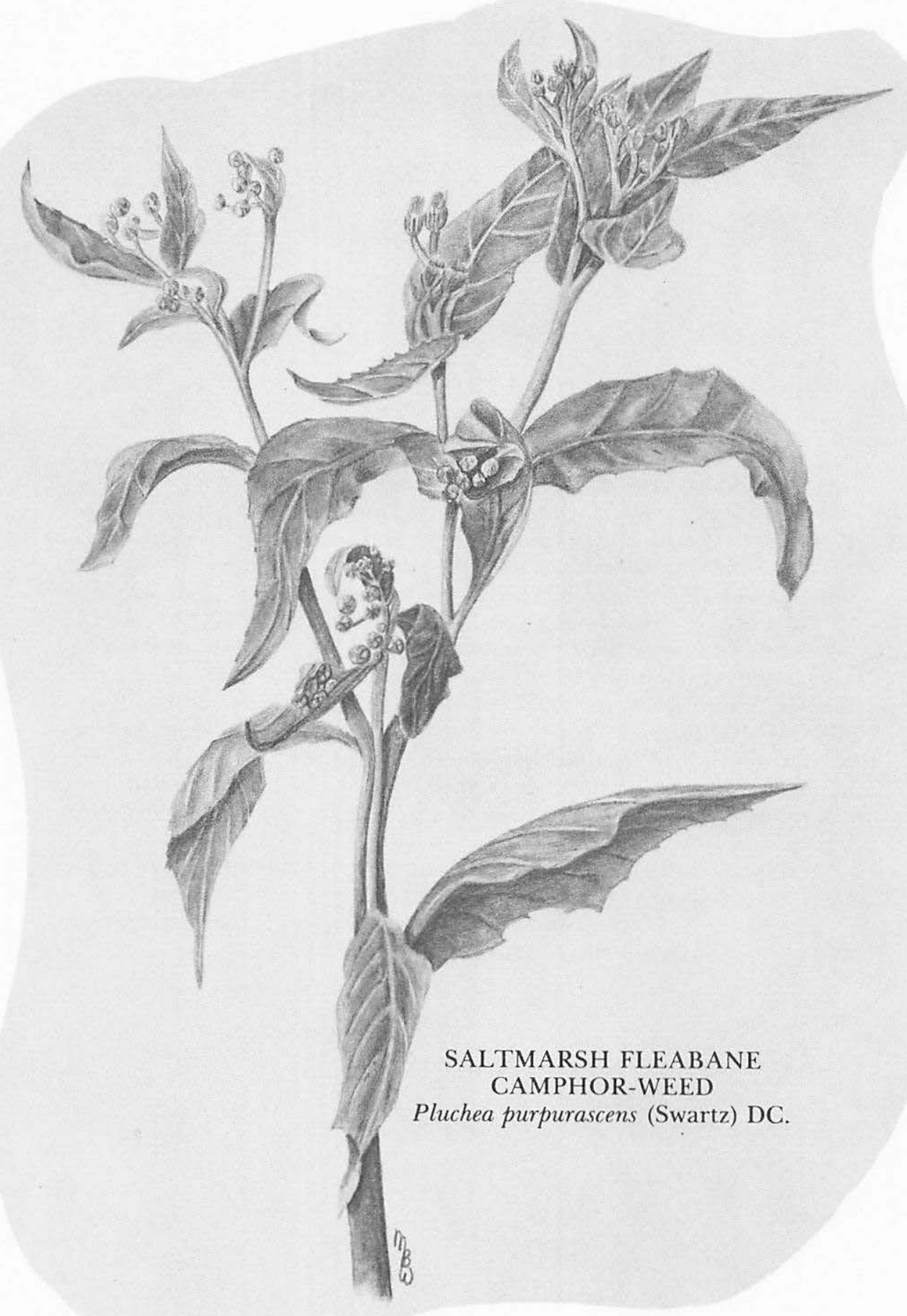




\section{SALTMARSH FLEABANE \\ CAMPHOR-WEED \\ Pluchea purpurascens (Swartz) DC.}

This pink flowered plant is often found in saltgrass meadow areas of brackish marshes. Belonging to the composite family, the tiny flowers are concentrated into flower heads, blooming from late July through October. The entire plant, especially the leaves, are pubescent (downy). The plants grow up to three feet high and are a striking contrast to the uniform appearance of the saltmeadows.

Another species, Pluchea foetida is somewhat similar to the above species except that it has white or cream-colored flowers and is not nearly as common.

Both species are coastal in distribution and range as far south as the West Indies. 


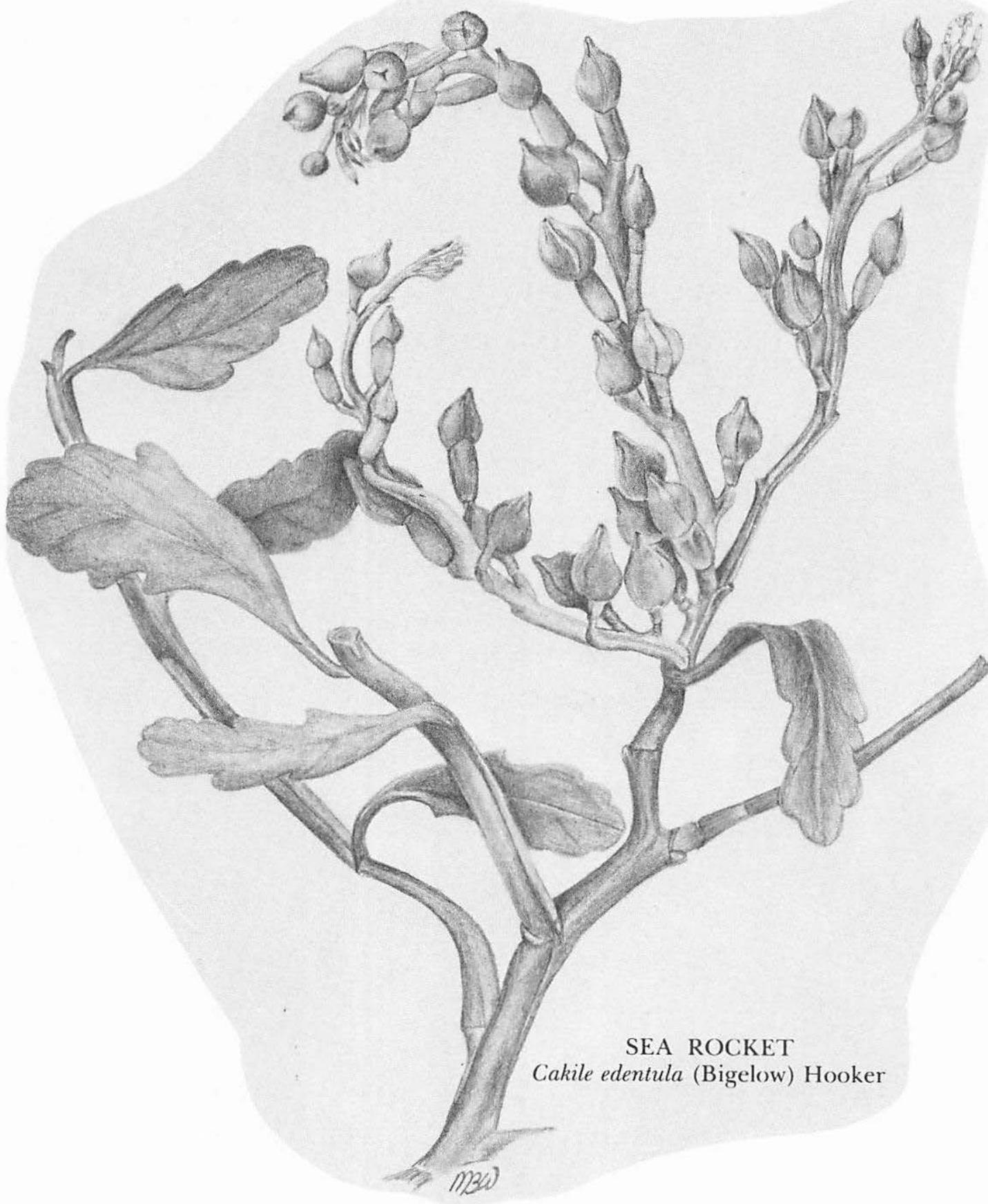


Sea Rocket is usually considered a beach species; however it often invades areas of coastal saltmarshes that are periodically overwashed by sand. It is a very succulent plant with thick, fleshy leaves and stems. The small flowers are usually lavender or light blue but occasionally white. The blooms have four petals, a distinguishing characteristic of the mustard family (Cruciferae) to which this plant belongs. 


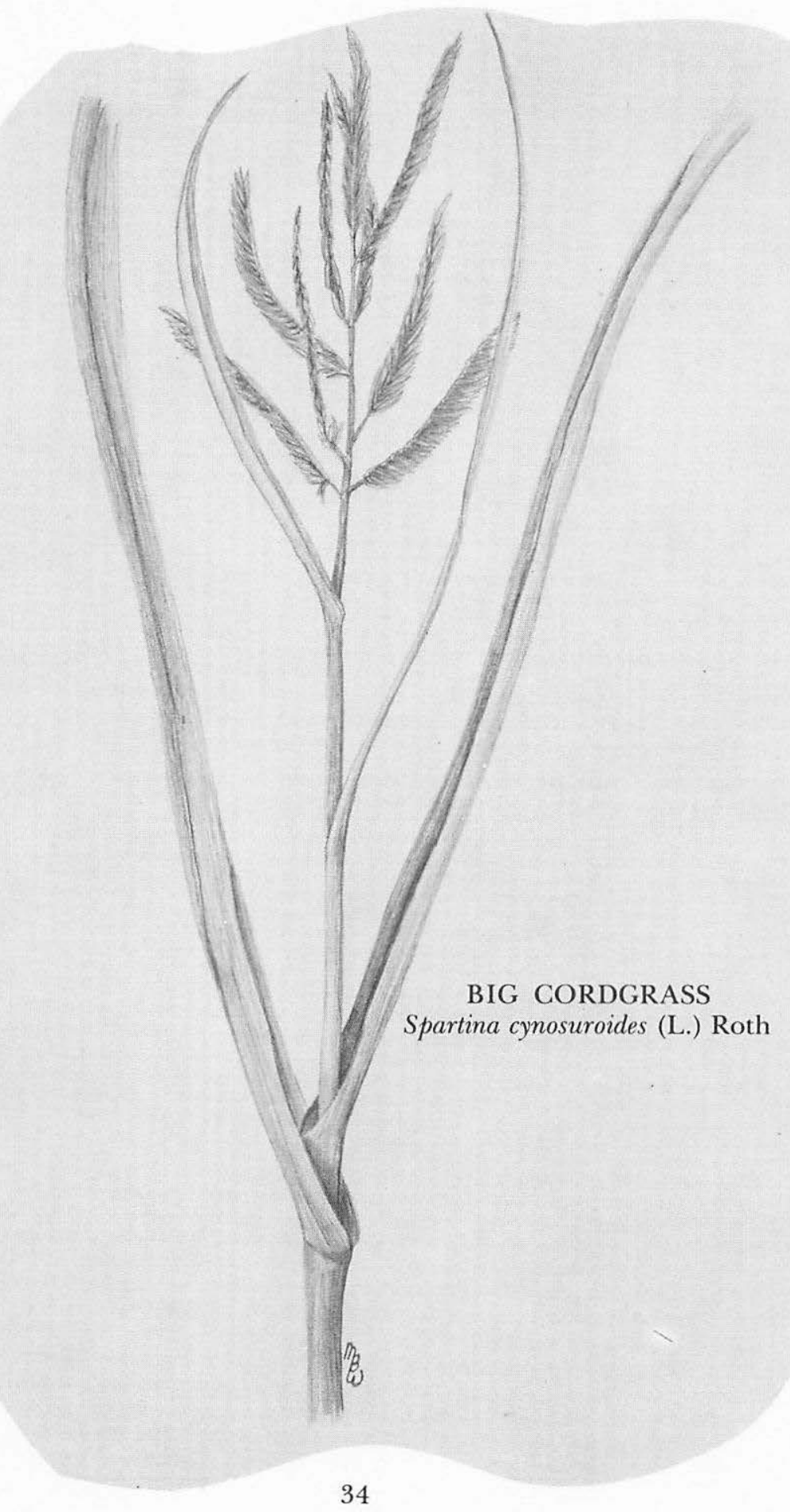




\section{BIG CORDGRASS}

Spartina cynosuroides (L.) Roth.

Big Cordgrass is the largest of the Spartina marsh grasses, often attaining heights of twelve feet or more in low salinity marshes. This very coarse perennial usually grows in dense, monospecific stands. In Virginia very large populations of this majestic grass occur along the Mattaponi and Pamunkey rivers, usually above the height of daily tides. The long tapering leaves are armed along the margins with minute upturned teeth. Many duck hunters have been cut when using this grass as camouflage for duck blinds.

The long, stout rhizomes of this grass are a favorite food for geese. Muskrats often use the foliage and stems for lodge construction.

Big Cordgrass ranges along the Atlantic and Gulf Coast's from New England to Texas. 


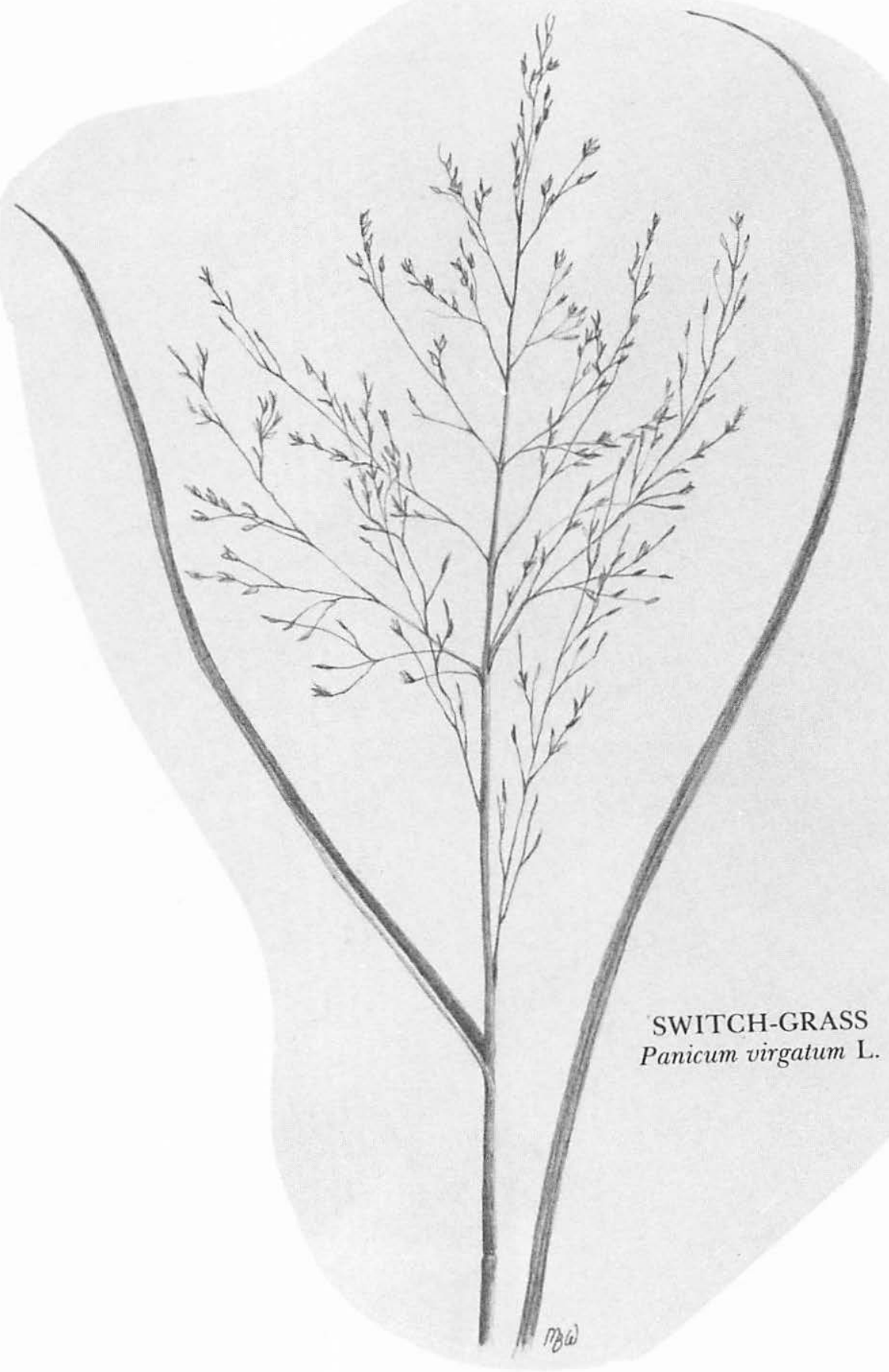




\section{SWITCH-GRASS}

Panicum virgatum $\mathrm{L}$.

Switch-grass is commonly found growing in tufts along the upper margins of the marsh. The open, delicately branched panicle with tiny florets at the tips of the "branches" are distinguishing features of this grass. The long, narrow leaves are concentrated in basal clumps or tufts. Leaves of the previous season are usually present, matted radially around the tuft.

Switch-grass is often associated with Groundsel Tree and Foxtail Grass Setaria geniculata in drier parts of the marsh. Switch-grass appears to invade the higher parts of the marsh that have been burned, often replacing marsh meadows. 


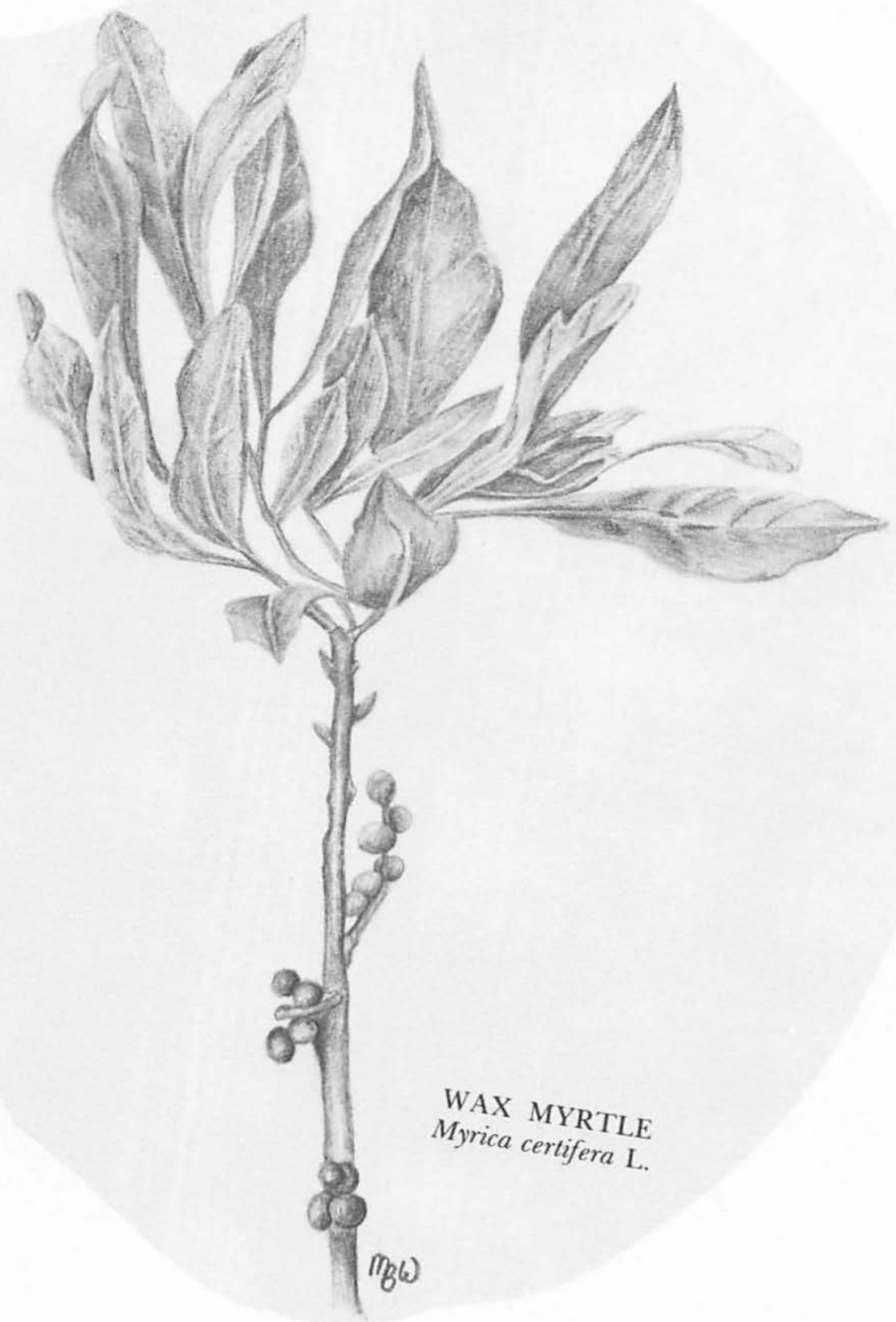


WAX MYRTLE

Myrica cerifera $\mathrm{L}$.

Wax Myrtle is a tall evergreen shrub which grows along the border of the uplands and the marsh. The dark green, leathery leaves have a spicy aroma as do the blue-gray waxy fruits. The wax from the fruits can be used for candle making; however thousands of berries are required for only one candle. The reddish-brown twigs (heavily resinous), the dark green leaves and the smooth gray bark give this shrub a very attractive appearance.

Wax Myrtle is often confused with the true Bayberries Myrica pensylvanica and Myrica heterophylla; however these have broader, larger leaves and larger fruit. They are not nearly as common in Virginia as is Wax Myrtle.

Wax Myrtle groves, as well as thickets of Marsh Elder and Groundsel Tree, serve as heronries on Virginia's Eastern Shore. On some heavily used sites, the guano becomes so thick that the shrubs eventually are killed. Tree Swallows also feed on the fruits in October. 


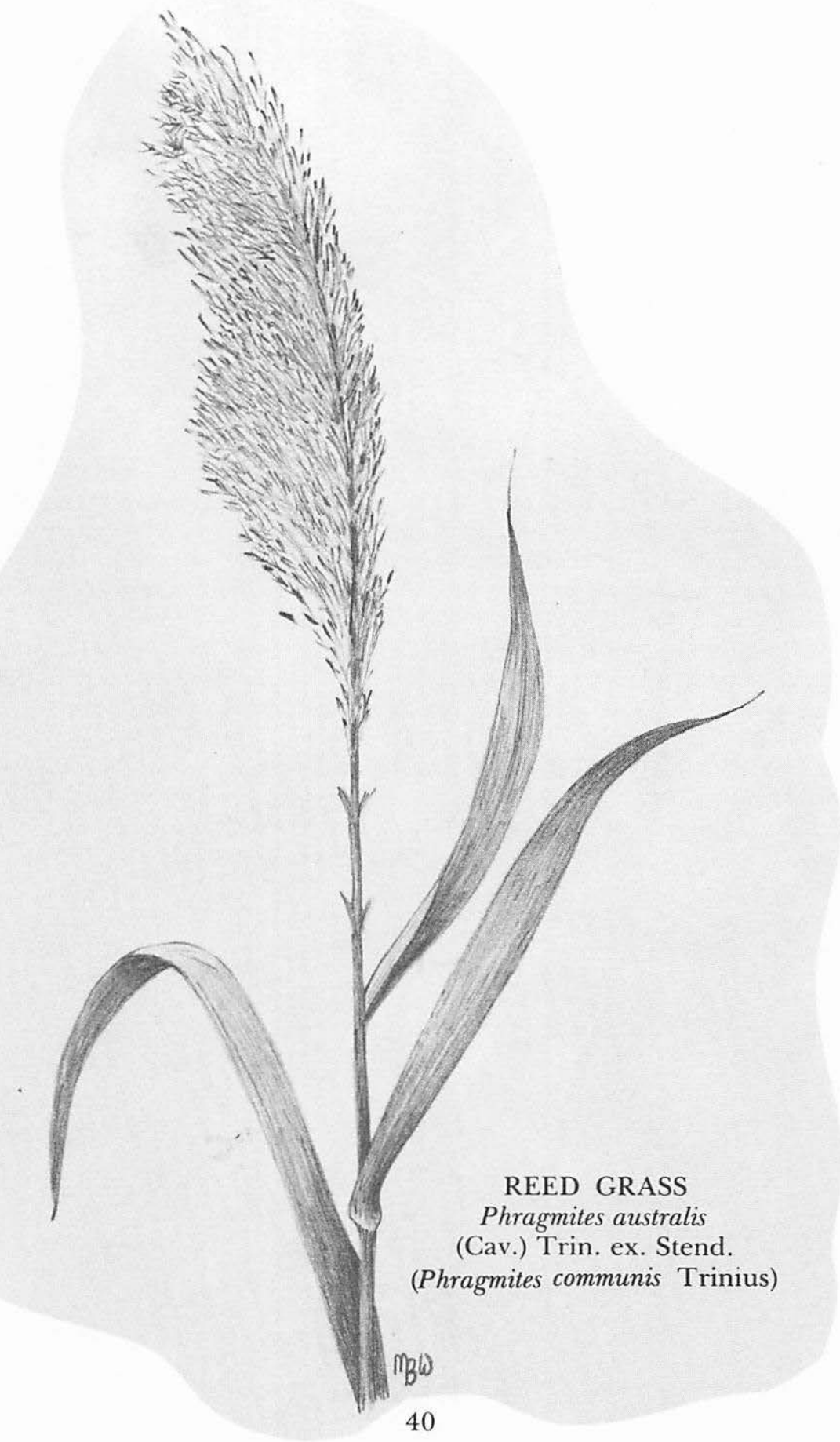




\section{REED GRASS \\ Phragmites australis (Cav.) Trin. ex. Stend. (Phragmites communis Trinius)}

A tall coarse grass with a feathery seed head, Reed Grass is a familiar invader of disturbed low or marshy areas. The broad, acutely tapering leaves, the characteristic seed head, and the very long rhizomes are trademarks for this giant grass which may grow to 12 feet high.

A very aggressive plant, the long, creeping rhizomes enable this grass. to vegetatively propagate dredged spoil areas very quickly. This valuable attribute aids in controlling erosion of spoil deposition areas. However, Reed Grass often competes successfully with other more valuable marsh plants such as Wild Rice and Big Cordgrass in some freshwater marshes. This competition is of potential concern to wetland managers.

Reed Grass is a very cosmopolitan plant, found throughout the world in both tidal and non-tidal freshwater marshes. In eastern Europe, the fibers from this grass are used for making paper.

Several studies have shown that Reed Grass marshes are effective assimilators of high nutrient loads originating from sewerage outfalls. These are recent experiments, however, and little is known as to what the long term impact will be on the ecology of the marsh. 


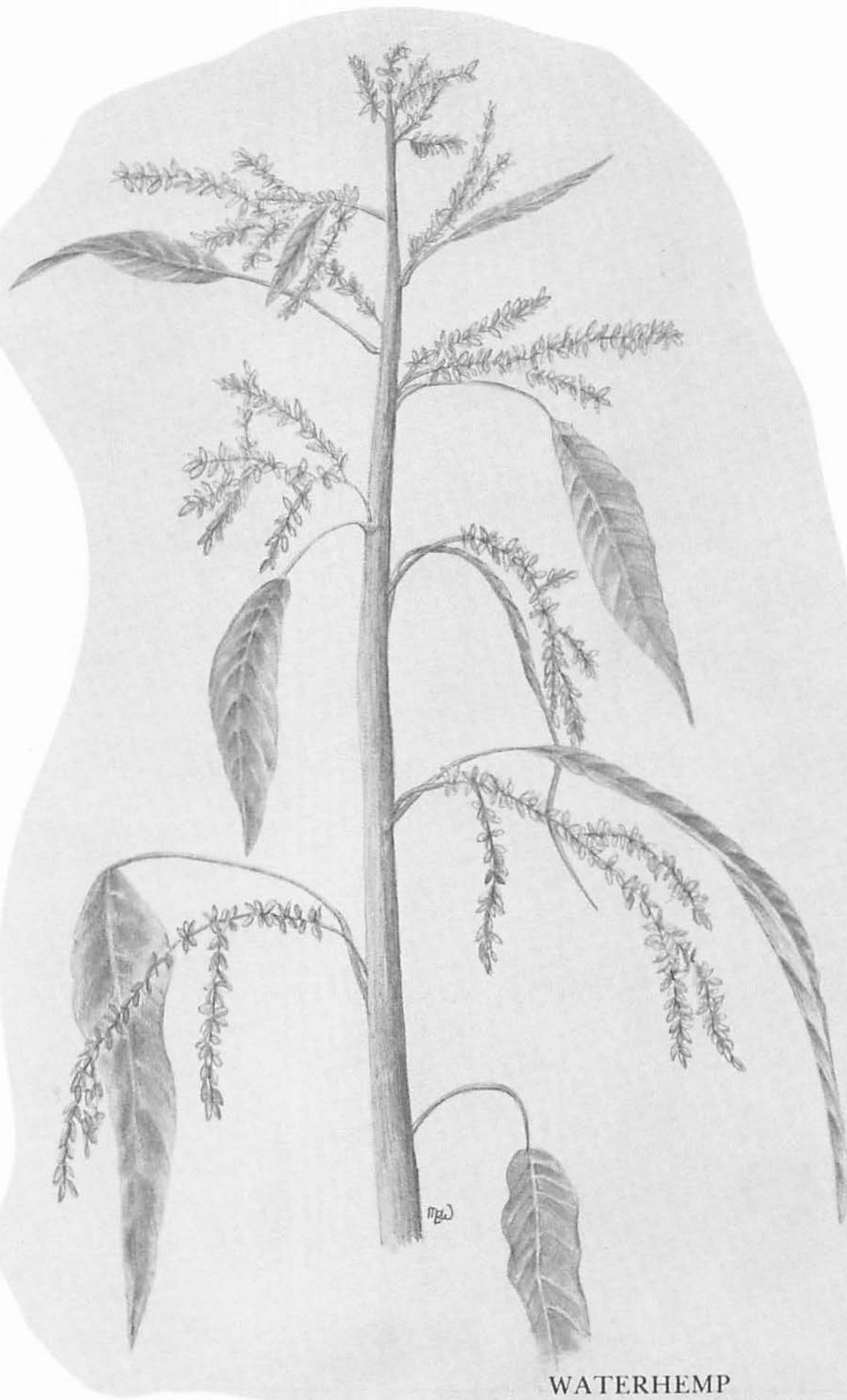

Amaranthus canabinus (L.) J.D. Sauer 


\section{WATERHEMP \\ Amaranthus canabinus (L.) J.D. Sauer}

Waterhemp is a tall, robust, willowy herb, which often reaches heights of 8 feet and is found in coastal marshes of various salinity regimes. $A$. canabinus is most common in brackish water and low salinity marshes. As the scientific name suggests, the overall appearance of the plant resembles that of Hemp, Cannabis sativa; however the resemblance ends here. The simple narrow, willow-like leaves of Waterhemp cannot be mistaken for the characteristic compound leaves of Cannabis.

In a typical coastal marsh dominated by grasses, sedges and rushes, the young plants of Waterhemp are not usually seen during the early part of the growing season; however by late summer the tree-like growth habit is quite obvious. When the plant is nearly mature, a profusion of many small, greenish or yellowish flowers are produced on leafy spikes or panicles. By fall a single large plant may produce a quart of seeds, a very important food for waterfowl.

Waterhemp ranges from Maine to Florida along the Atlantic Coast. 


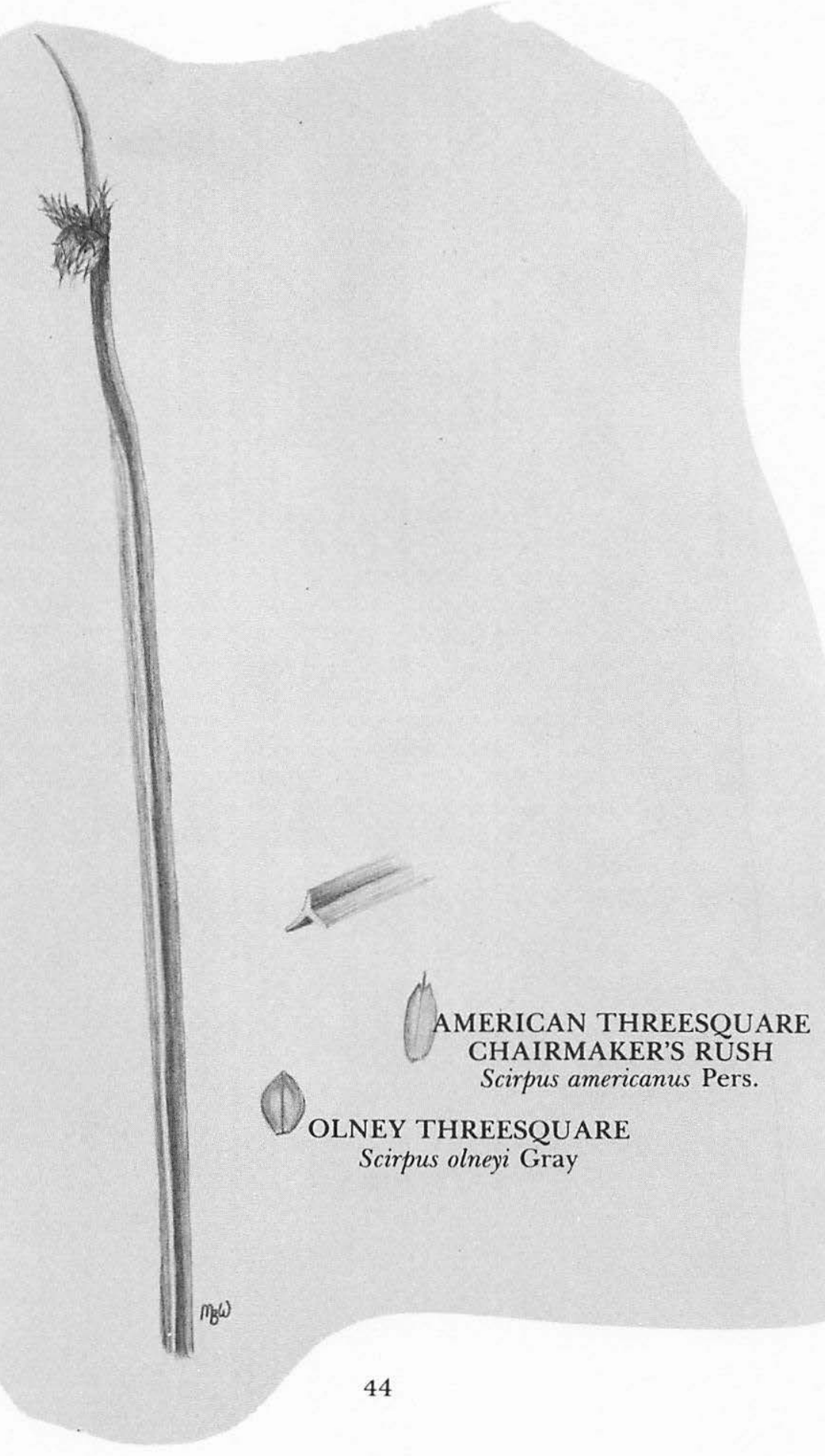




\section{OLNEY THREESQUARE}

Scirpus olneyi Gray (illustrated)

\section{AMERICAN THREESQUARE CHAIRMAKER'S RUSH Scirpus americanus Pers.}

These two sedges are quite distinct from any other grass-like plants of brackish or freshwater marshes. Both have triangular stems in crosssection and have very few if any stem leaves at maturity. The seed clusters appear to extend laterally from the stem near the apex. The seeds are eaten by waterfowl.

Although the two species are quite similar, there are distinguishing differences. Olney Threesquare usually grows in more saline situations than does American Threesquare. Also, the seed clusters of Olney Threesquare are situated closer to the apex than they are in American Threesquare.

A closer look at the seed clusters of the two species (by use of a hand lens) reveals more detailed differences in the scales that subtend the clusters. The scales of $S$. americanus have a characteristically notched apex and a minute needle-like extension, whereas the scales of $S$. olneyi have a broad, obtuse apex (see illustration).

In Tidewater, Threesquare marshes probably support the most muskrats, as revealed by pelts taken by trappers. 


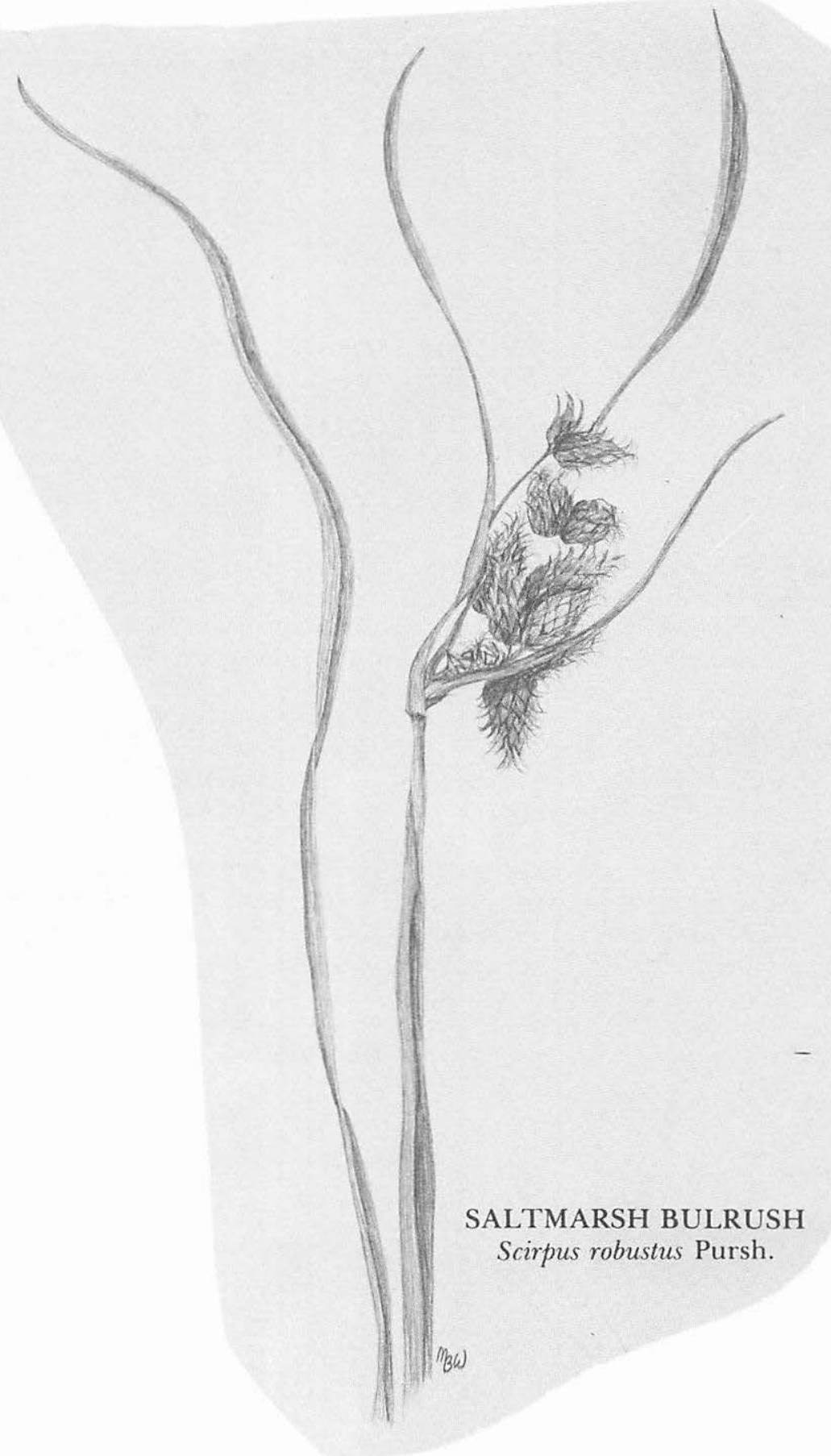




\section{SALTMARSH BULRUSH \\ Scirpus robustus Pursh.}

As the scientific name suggests, this sedge is not only robust in stature but also in its development of a large cluster of brown seed heads in late summer. It is often called Threesquare because of its triangular-shaped stem. However, unlike the other Threesquares commonly found in low salinity marshes, Saltmarsh Bulrush has a number of prominent stem leaves. Olney Threesquare and American Threesquare have very few leaves and these are usually missing late in the growing season.

The brown lustrous seeds of Saltmarsh Bulrush are a favorite food for waterfowl. Also important are the stems and leaves of this sedge, being one of the materials for muskrat lodge construction. Because of these values, Saltmarsh Bulrush is often planted in order to improve waterfowl and wildlife habitats. 


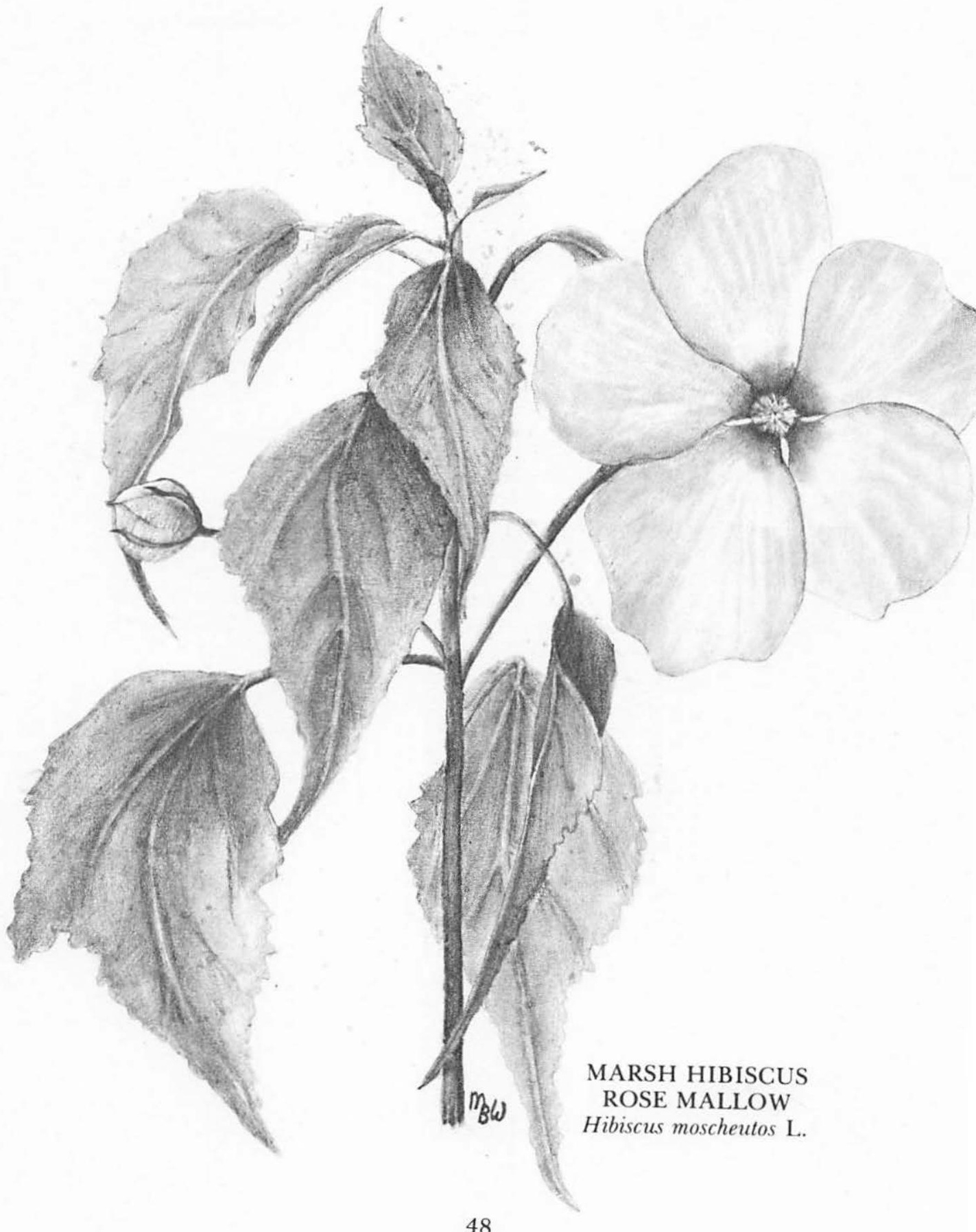




\section{MARSH HIBISCUS \\ ROSE MALLOW \\ Hibiscus moscheutos $\mathrm{L}$.}

A tall, leafy, perennial, Marsh Hibiscus is commonly found in freshwater marshes or along the upland margin of saline marshes where freshwater seepage dilutes saltier water from the estuary. The large showy white or pinkish blossoms, often six inches wide or more, are distinctive characteristics of this robust plant.

Belonging to the same family (Malvaceae) as cotton, Marsh Hibiscus resembles a cotton plant in bloom and is sometimes called Wild Cotton. However, this is where the similarity ends. Hibiscus does not develop the cotton ball as does its domesticated relative.

There are two other species of this same family that grow in tidal marshes in Virginia. Althaea officinalis, the true Marsh Mallow, is seldom found in Virginia's saltmarshes. During colonial times a confection was made from the mucilaginous roots of this plant. A similar plant, Kosteletskya virginica, also called Marsh Mallow, is commonly found in brackish water marshes. 


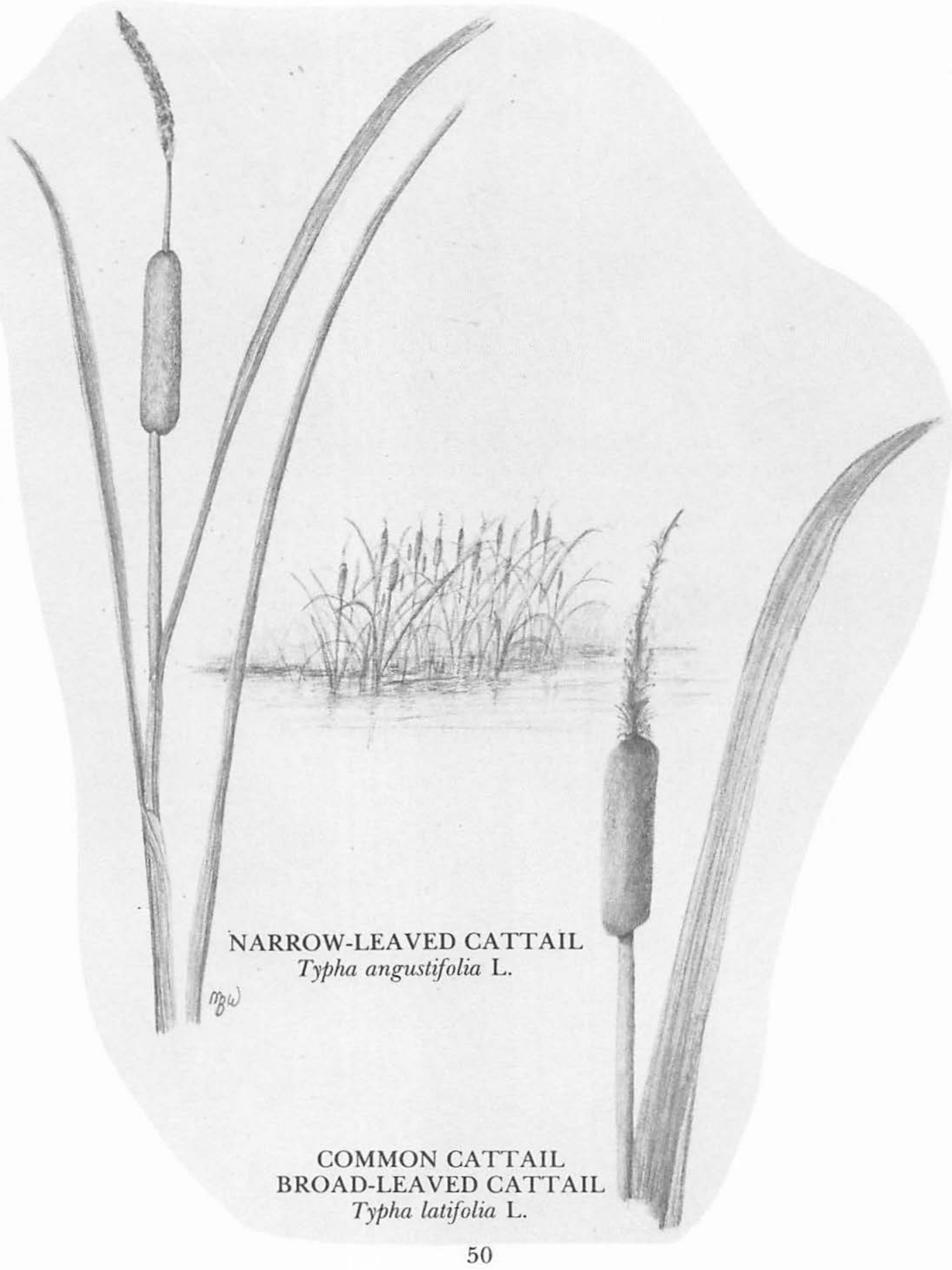




\section{NARROW-LEAVED CATTAIL \\ Typha angustifolia $\mathrm{L}$. \\ COMMON CATTAIL \\ BROAD-LEAVED CATTAIL \\ Typha latifolia $\mathrm{L}$.}

The two most common Cattails found in Virginia's tidal marshes (brackish and freshwater) are the Narrow-leaved and Broad-leaved Cattails.

Typha angustifolia is commonly found in brackish and freshwater marshes. It has narrow leaves (about $1 / 4$ to $1 / 2$ inch wide) and the characteristic spike has a distinct gap between the upper male portion (staminate) and the lower female (pistillate) portion. In brackish marshes, Narrow-leaved Cattails are typically found in dense colonies along the upland margin where there is freshwater seepage.

Typha latifolia, the Broad-leaved Cattail, is more common in freshwater marshes. This species has no (or only a slight) gap between the staminate and pistillate portions of the spike and has leaves up to $1 \frac{1}{2}$ inches wide.

The rootstocks of both species are eaten by geese and muskrats. In the spring, the young emerging plant can be eaten. Later in the season the tender developing spike is also edible. Both plant parts are considered a delicacy by many individuals. 

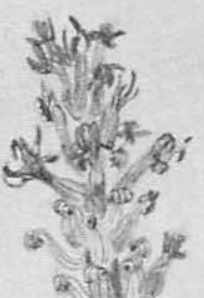

3 क्रीक
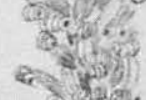

Q

(2) 190
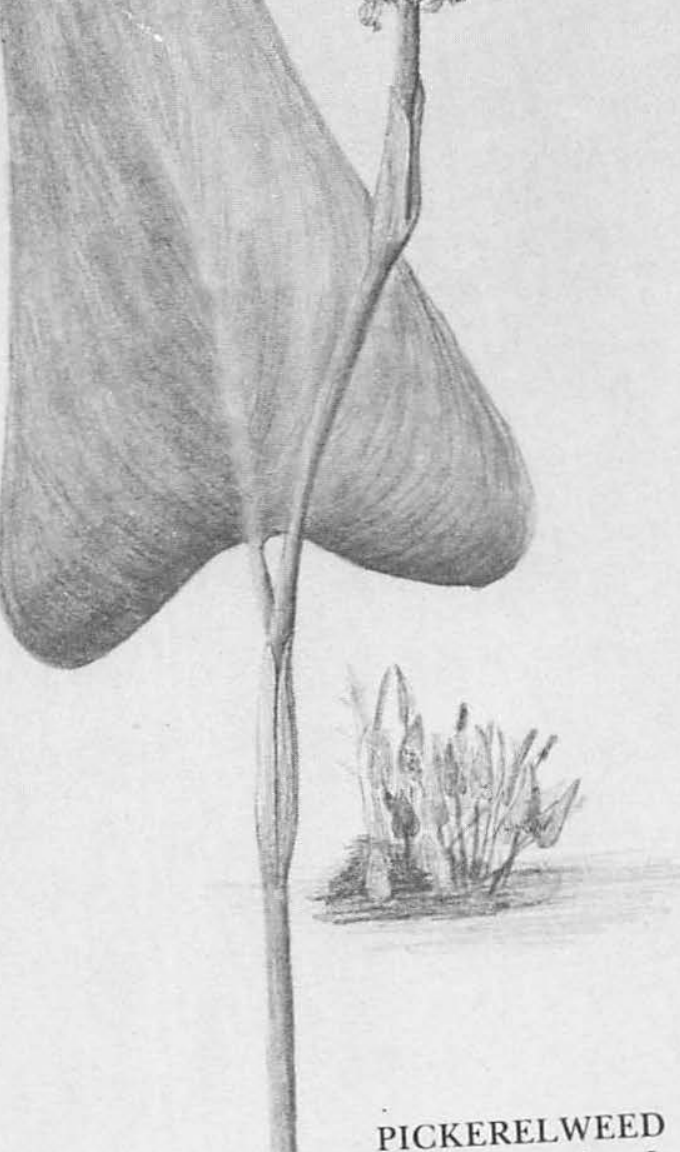

Pontederia cordata L.

$\mathrm{BP}(\mathrm{D}$ 


\section{PICKERELWEED}

Pontederia cordata L.

Pickerelweed often grows in association with Arrow Arum Peltandra virginica in the intertidal zone of freshwater marshes. Both plants have fleshy leaves of similar shape that emerge from underground rhizomes. The leaves of Pickerelweed are somewhat heart-shaped with an array of veins closely paralleling the general shape of the leaf. Arrow Arum, in comparison, has larger, triangular-shaped leaves with three dominant and many subordinate veins.

This plant has a spike of blue flowers subtended by a single leaf-like bract (see illustration). During the blooming season, which may extend from May until October, a marsh dominated by this plant will have a characteristic blue hue, contrasting with dark green foliage. During the winter, however, the above ground portion of the plant quickly decomposes leaving only bare mud flats.

Pickerelweed serves as a food source for several species of wildlife. The sticky red seeds are eaten by Black Ducks while the thick, short rhizomes are eaten by muskrats. 


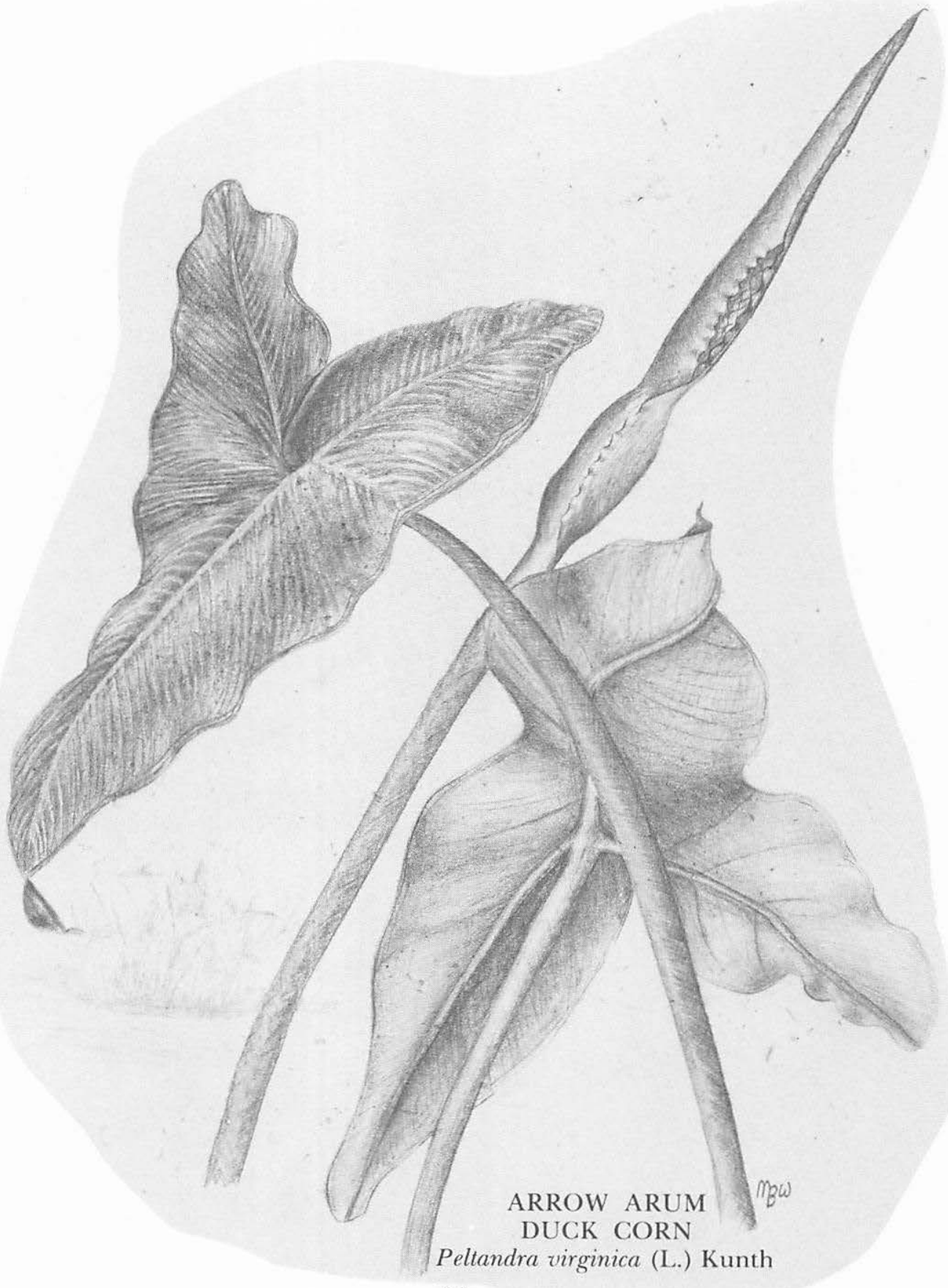




\section{ARROW ARUM \\ DUCK CORN}

Peltandra virginica (L.) Kunth

Arrow Arum or Duck Corn is an emergent, fleshy perennial found in the intertidal areas of freshwater marshes. It is often associated with Pickerelweed, Pontederia cordata. Its dominant characteristics are the large triangular leaf blades (up to 3 feet long) and the pod-like fruiting head. Arrow Arum grows in rather dense clumps with leaves (emerging from rhizomes) attaining heights from 3 to 7 feet. Not necessarily a coastal plant, Arrow Arum is found in wetland areas throughout the southeastern part of the country.

In late May or June, an elongated, leaf-like, reproductive appendage develops. It resembles a pointed rolled leaf (spathe) that surrounds a fleshy, cylindrical infloresence (spadix). These are characteristic features of the Araceae family to which Arrow Arum belongs, along with Sweet Flag, Acorus calamus, another freshwater marsh plant.

During late summer and early autumn, the infloresence is transformed into a pod-like seed case (spathe enclosing seeds) which droops to the marsh mud and decays, eventually releasing the seeds. The dark green to black, fleshy seeds ( $3 / 8$ inch in diameter) are produced in great numbers and are distributed by the tides for many miles. The oxalic acid content is very high and only Wood Ducks eat them regularly. In the spring of the year, the seeds from the previous fall secrete a clear gelatinous mass that often attains the size of a golf ball. 


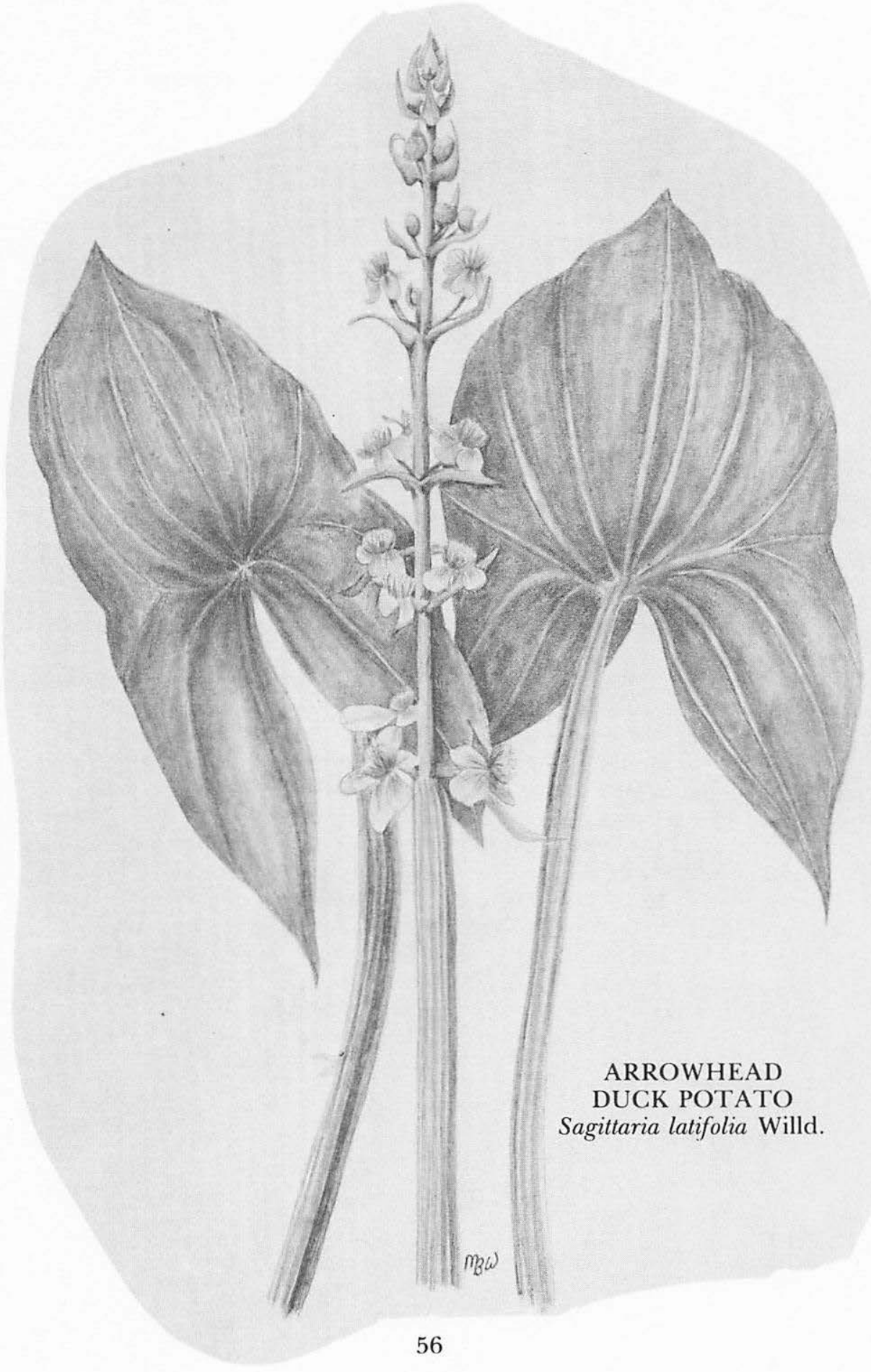




\section{ARROWHEAD \\ DUCK POTATO \\ Sagittaria latifolia Willd. (illustrated) \\ Sagittaria falcata Pursh. \\ Sagittaria graminea Michx.}

Although the common name Arrowhead is broadly applied to all species of the genus Sagittaria, not all of them have the characteristic arrowhead-shaped leaf. $S$. falcata, for example, has lance-shaped leaves and the leaves of $S$. graminea are grass-like. Features common to all species of this genus are the white tri-petal flowers with yellow staminate centers and tubers that are produced at the ends of rhizomes. The name Duck Potato is derived from the fact that the tubers are eaten by numerous waterfowl.

In tidal freshwater marshes, Arrowhead colonies are rarely prominent. They are usually found in the intertidal zone, which is generally dominated by Arrow Arum and Pickerelweed. S. latifolia and S. falcata are the most common Arrowheads found in Virginia's tidal marshes. $S$. latifolia and S. graminea range throughout much of eastern United States and Canada while $S$. falcata is more restricted to the coastal plain from Delaware to Florida and the Gulf of Mexico. 


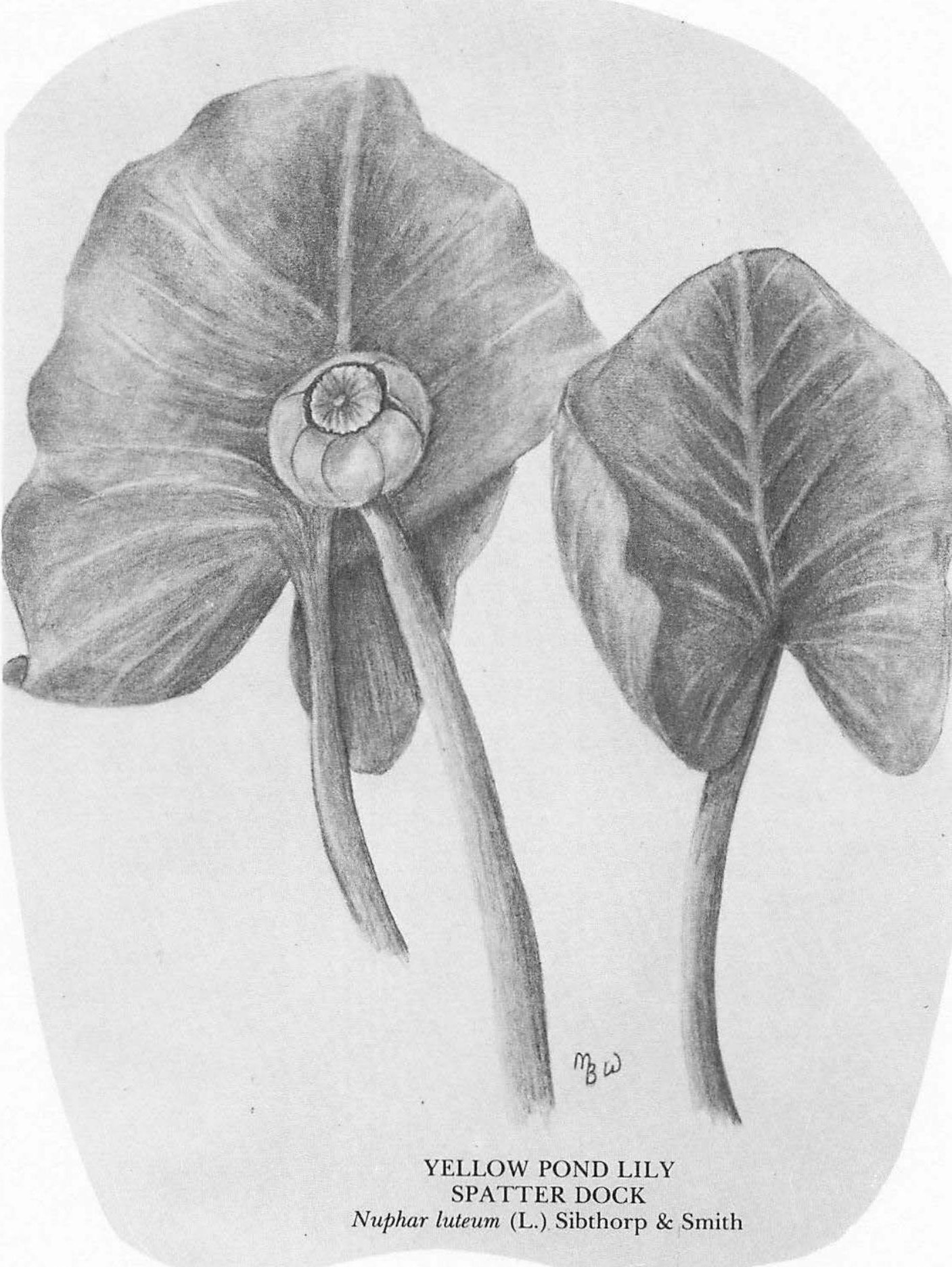




\section{YELLOW POND LILY \\ SPATTER DOCK \\ Nuphar luteum (L.) Sibthorp \& Smith}

Yellow Pond Lily is the most common plant growing in standing water in Virginia's tidal freshwater marshes. At high tide the round or heart-shaped leaves are often floating, while at low tide they may extend several feet above the water surface. The leaves and flower stalks originate from stout rhizomes imbedded in the bottom mud. The flowers are solitary and stout, with yellow, leathery, petal-like sepals.

Although Yellow Pond Lily has little value as a waterfowl food, it does provide cover and attachment sites for aquatic animals and algae. 


$$
16
$$


SWEET FLAG

Acorus calamus $L$.

Sweet Flag grows in dense colonies in freshwater marshes propagating mainly by rhizomes. The general appearance of this plant is very similar to that of grasses or sedges with wide sword-like leaf blades. Upon closer observation, however, it can be seen that an elongated, cylindrical inflorescence emerges from leaf-like stems. This reproductive appendage is called a spadix, a spike of compacted fleshy flowers. This structure is similar to that of Arrow Arum, except in Sweet Flag, the spadix is not surrounded by a spathe.

Sweet Flag, is so named because all parts of the plant, particularly the rhizomes, have a sweet aromatic taste and odor. Acrous is seldom a dominant plant in the tidal freshwater marshes of Virginia. Muskrats prize the roots for food. 


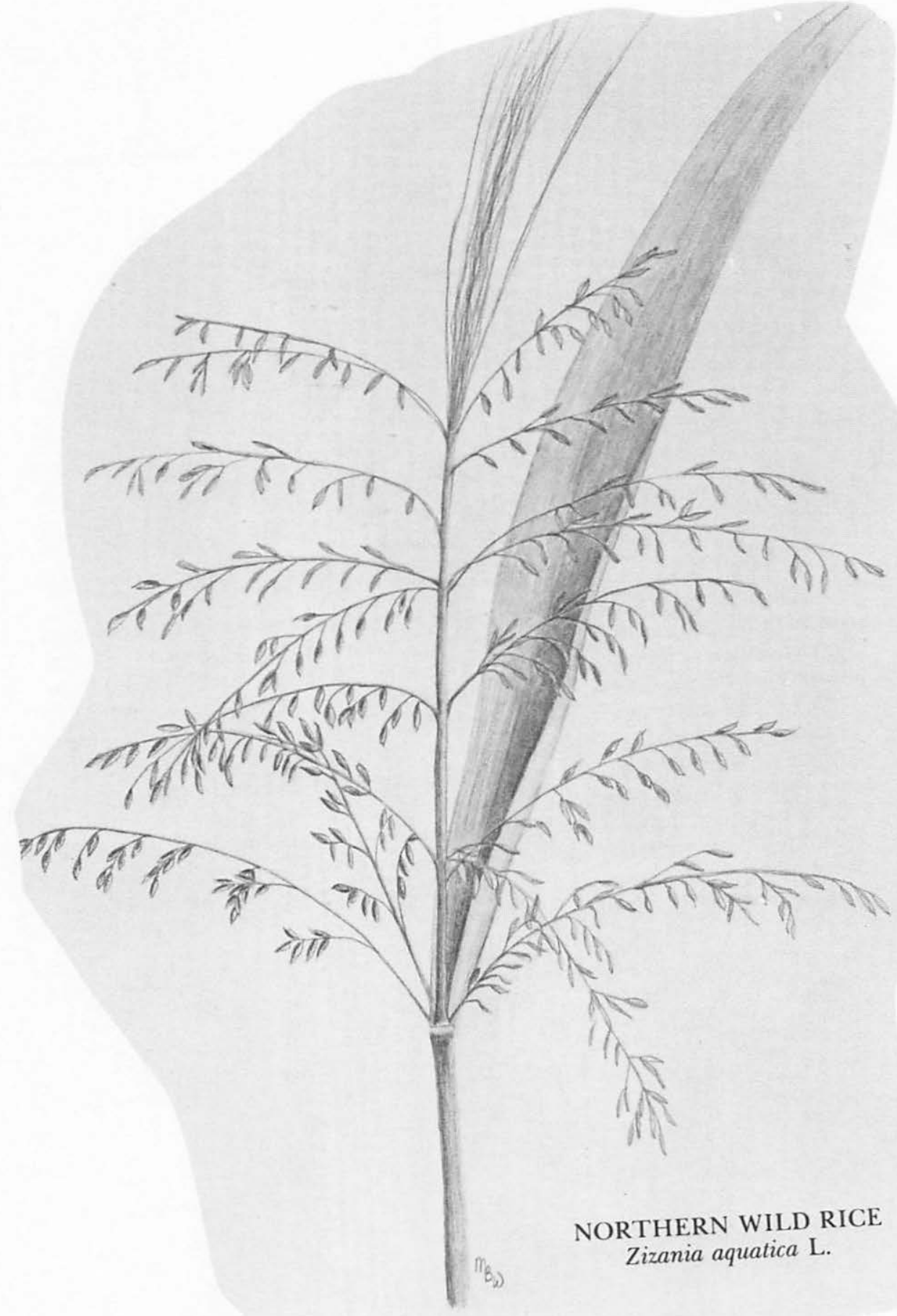




\section{NORTHERN WILD RICE \\ Zizania aquatica L. (illustrated) \\ SOUTHERN WILD RICE \\ Zizaniopsis miliacea (Michx.) \\ Doll \& Aschers.}

There are two different species of Wild Rice found in Virginia's freshwater marshes, Northern Wild Rice and Southern Wild Rice.

Northern Wild Rice Zizania aquatica is the predominant species in Virginia. It is found in non-tidal as well as tidal freshwater marshes and ranges from Maine to Florida along the coast and interior to Minnesota and North Dakota. It's rice-like grains in late fall are highly valued as waterfowl food. However, the soft immature grains of late summer or early autumn are usually eaten by Red-winged Blackbirds before the great flocks of ducks and geese arrive from the north. Wild Rice has different varieties and growth forms. However, the distinguishing characteristic common to all varieties is the arrangement of the staminate (male) and pistillate (female) flowers on the panicle (infloresence). The lower branches of the panicle contain the staminate flowers while the upper part is composed entirely of pistillate flowers which eventually develop into rice grains. The typical variety of Wild Rice has leaves up to 3 feet long and 2 inches wide with tiny saw-like teeth on the margins that can cut tender skin.

Southern Wild Rice, Zizaniopsis miliacea, ranges from Maryland to Florida and Texas. The vegetative portions of Southern Wild Rice are somewhat similar to Northern Wild Rice. However, the panicle of the more southern species is not separated into distinct reproductive branches. The pistillate and staminate flowers (spikelets) are on the same branches.

The largest populations of Wild Rice in Virginia are found in the marshes of Pamunkey, Mattaponi and upper Rappahannock rivers. Northern Wild Rice is the dominant species in these areas. 


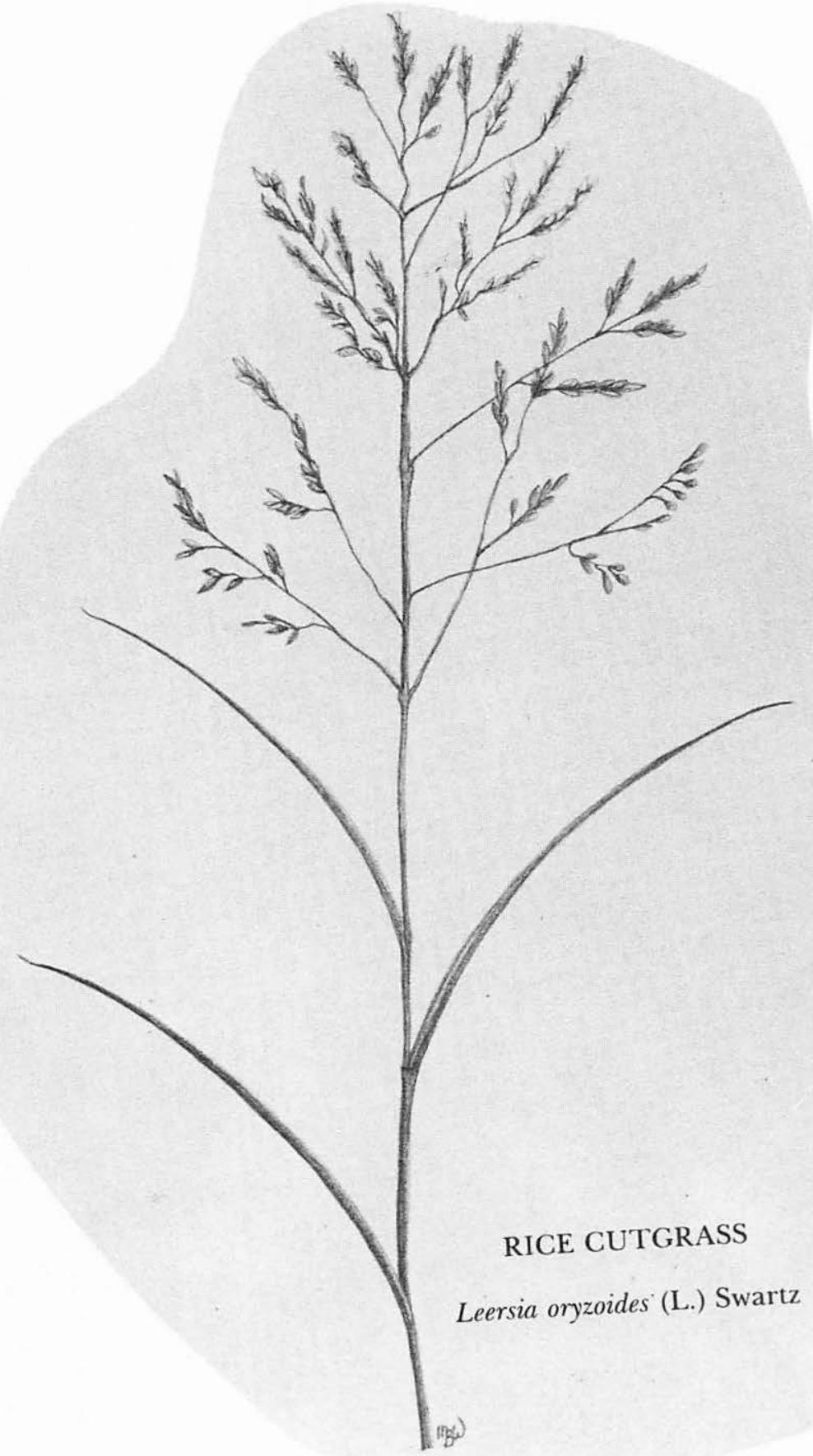


RICE CUTGRASS

Leersia oryzoides (L.) Swartz

Rice Cutgrass colonies form dense matted and tangled thickets in freshwater marshes and swamps. The stems may obtain lengths of 3 feet or more but become weakened shortly after maturity. During the height of anthesis (flowering time), which reaches its peak in October, the flowering heads are a noticeable yellowish-green. It is a definite contrast with the other marsh vegetation which, for the most part, is well past the blooming period.

The leaf margins are very rough because of many minute teeth (spinules), hence the name Cutgrass. The reddish grain is eaten by waterfowl. Rice Cutgrass is common throughout much of continental United States in wetland areas. 


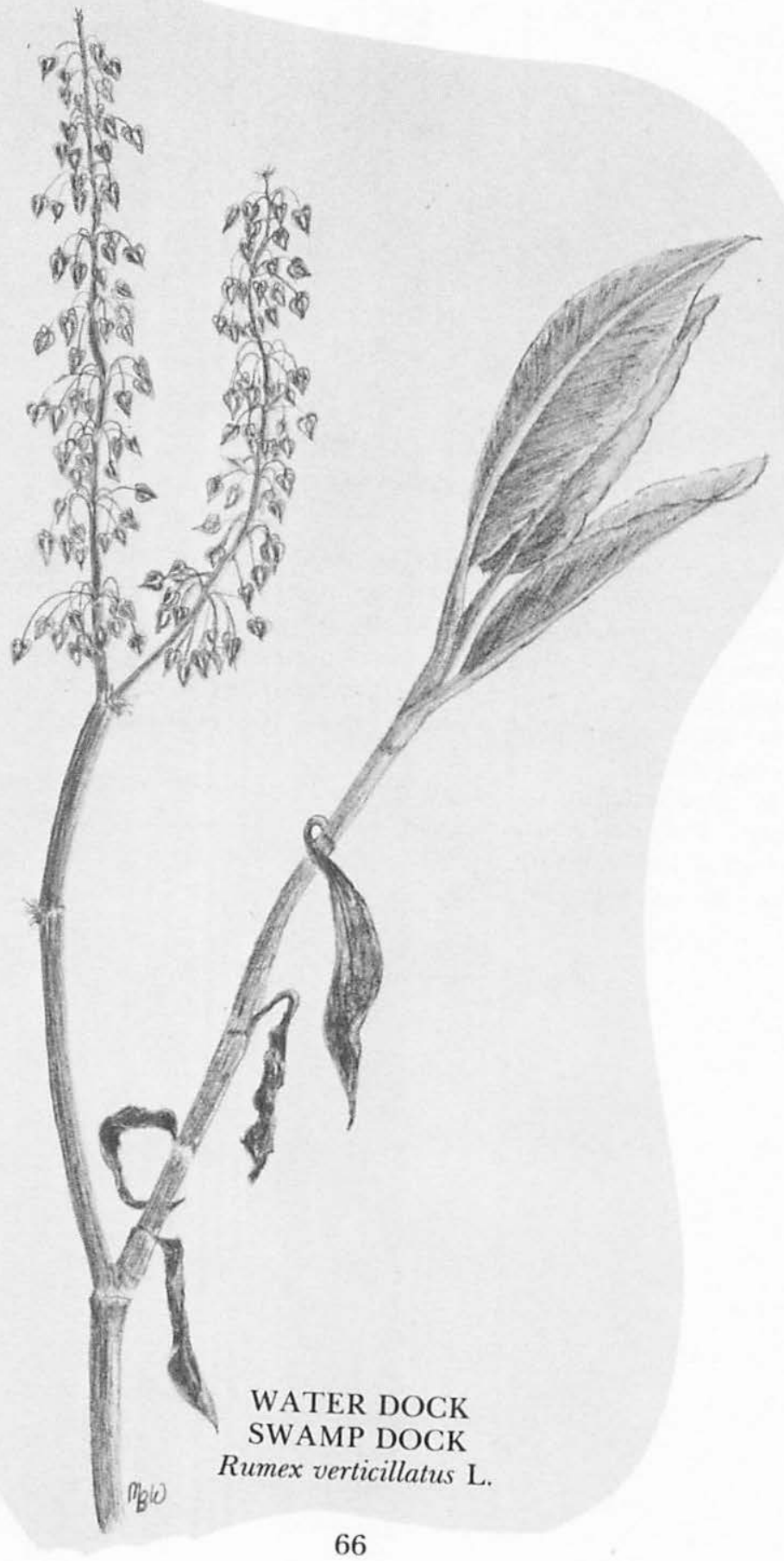




\section{WATER DOCK \\ SWAMP DOCK \\ Rumex verticillatus $\mathrm{L}$.}

Water Dock, an erect, robust plant with dark green, lance-shaped leaves, grows in dense colonies in tidal freshwater wetlands. The elongated, greenish flower head (raceme) is evident in late spring or early summer. By mid-to-late summer, the flowers are transformed into dry, dark brown fruits, arranged in whorls on the terminal stem. A thin, tissue-like sheath (ocrea) is located at each leaf node, one of the distinguishing features of the family Polygonaceae. The lower leaves wither during the late summer months, but remain on the stem until late fall, when eventually the entire plant decays.

Primarily a coastal wetland species, Water Dock ranges from the mid-Atlantic region to Alabama.

The seeds are eaten by waterfowl during fall migration. 


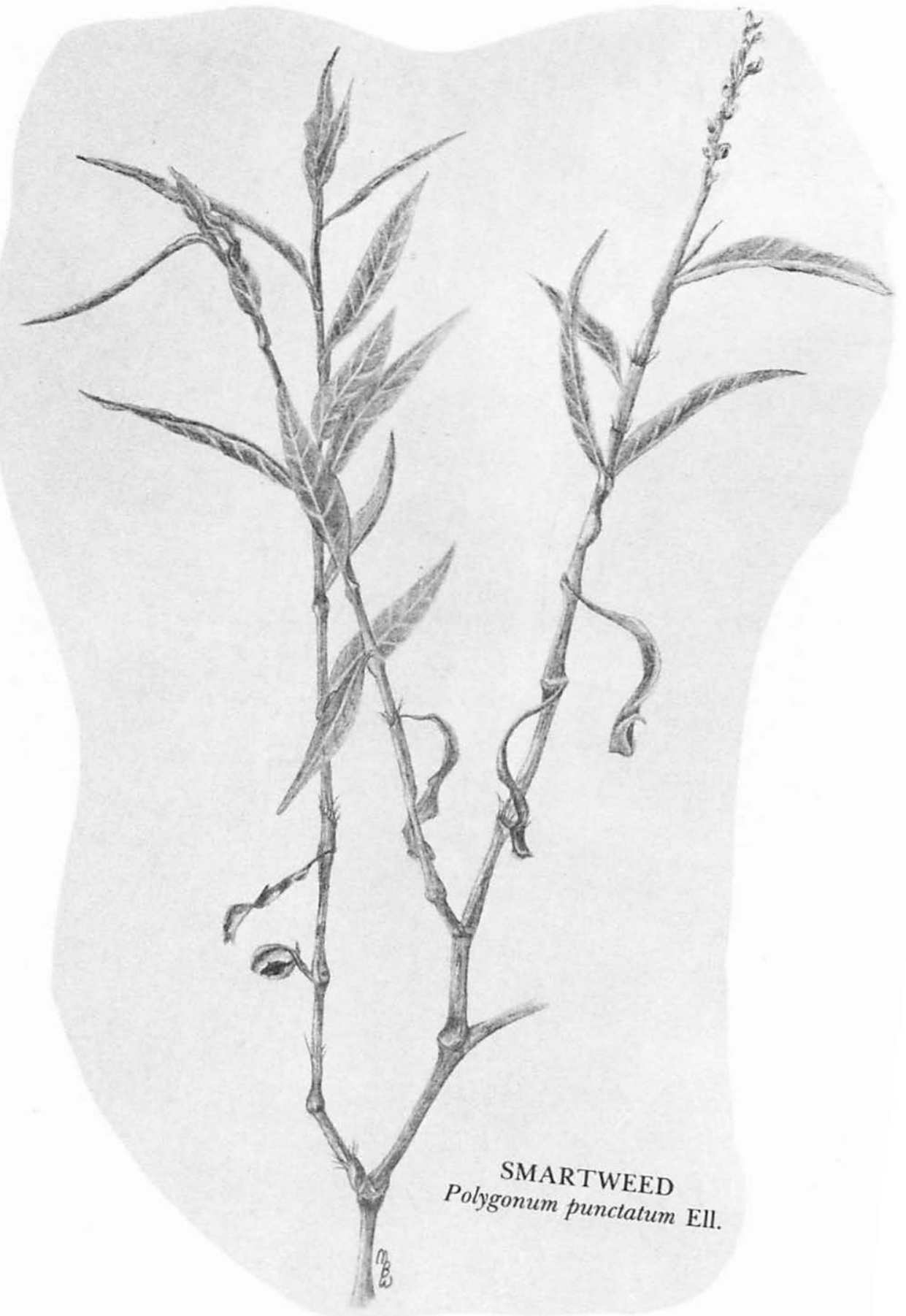


SMARTWEEDS

Polygonum punctatum Ell. (illustrated)

Polygonum densiflorum Meissner

Polygonum hydropiperoides Michaux

Three species of Smartweeds are commonly found in tidal freshwater marshes, with $P$. punctatum being the most abundant. These plants are usually associated with Arrow Arum and Pickerelweed in the intertidal zone. The tiny whitish, greenish or pinkish flowers form a terminal, elongated cluster (raceme) that blooms from early summer to frost. The narrow, willow-like leaves, the somewhat swollen leaf nodes and the tissue-like ocreae (see Water Dock) are distinguishing features of these Smartweeds. Characteristically, the leaves wither and die but remain on the stem until late in the season.

The lustrous black or brown seeds are relished by ducks in the fall. Seeds and rhizomes of Smartweeds are sometimes planted in marshes in order to attract waterfowl.

$P$. densiflorum is mainly an Atlantic Coastal Plain plant whereas the other two species range throughout much of the North American continent. 


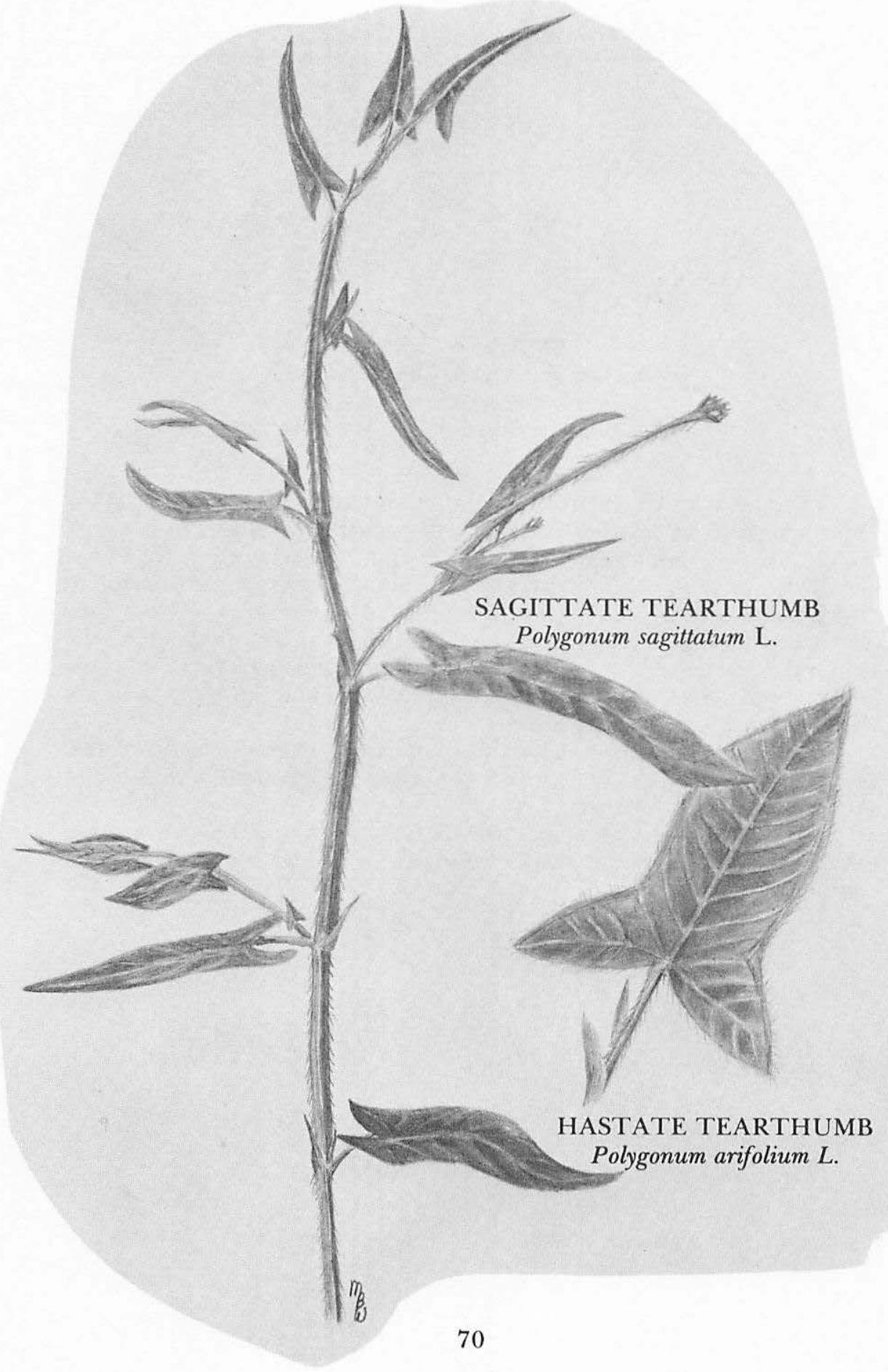




\section{TEARTHUMBS \\ SAGITTATE TEARTHUMB \\ Polygonum sagittatum $\mathrm{L}$. \\ HASTATE TEARTHUMB \\ Polygonum arifolium $\mathrm{L}$.}

Tearthumbs are commonly found in freshwater marshes where they form matted intertwining thickets with other marsh plants. Both species have downward trending barbs on their sharply angled stems and leaf petioles, thereby the name, Tearthumb. The seeds are similar to those of Smartweeds and are eaten by waterfowl.

Although the barbed, sprawling stems are common to both species, there are characteristics that distinguish one from the other. Sagittate Tearthumb has narrow, smooth leaves with sagittate basal leaf lobes (pointing downward) whereas Hastate Tearthumb has broad pubescent (downy) leaves with hastate basal lobes (nearly at right angles). These features are indicated in the illustration.

Both species range throughout the eastern half of the United States and Canada although Hastate Tearthumb is more prevalent in the coastal areas, especially in Virginia and North Carolina. 


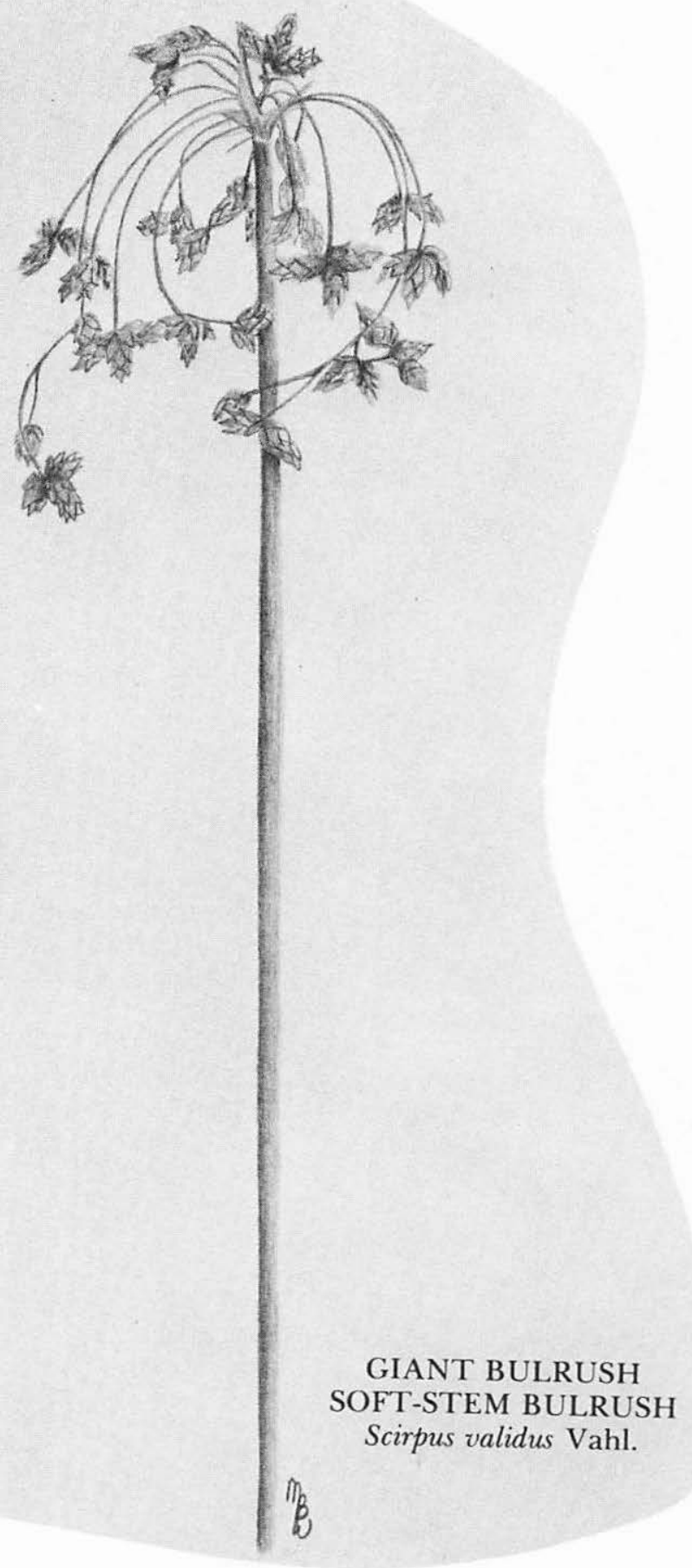




\section{GIANT BULRUSH \\ SOFT-STEM BULRUSH \\ Scirpus validus Vahl.}

A majestic rush-like sedge, Giant Bulrush forms colonies in freshwater marshes and may grow to heights of 10 feet. The round, long tapering stems are soft to the touch, hence it is also known as Soft-stem Bulrush. The leaves are reduced to inconspicuous sheaths at the base of the stem. The terminal, brownish panicle is evident by mid-summer. Colonies are found in the lower parts of the marsh, often associated with Arrow Arum and Pickerelweed. The stems and underground rhizomes are a favorite food of muskrats.

Giant Bulrush can be found in wetland areas throughout most of continental United States. 


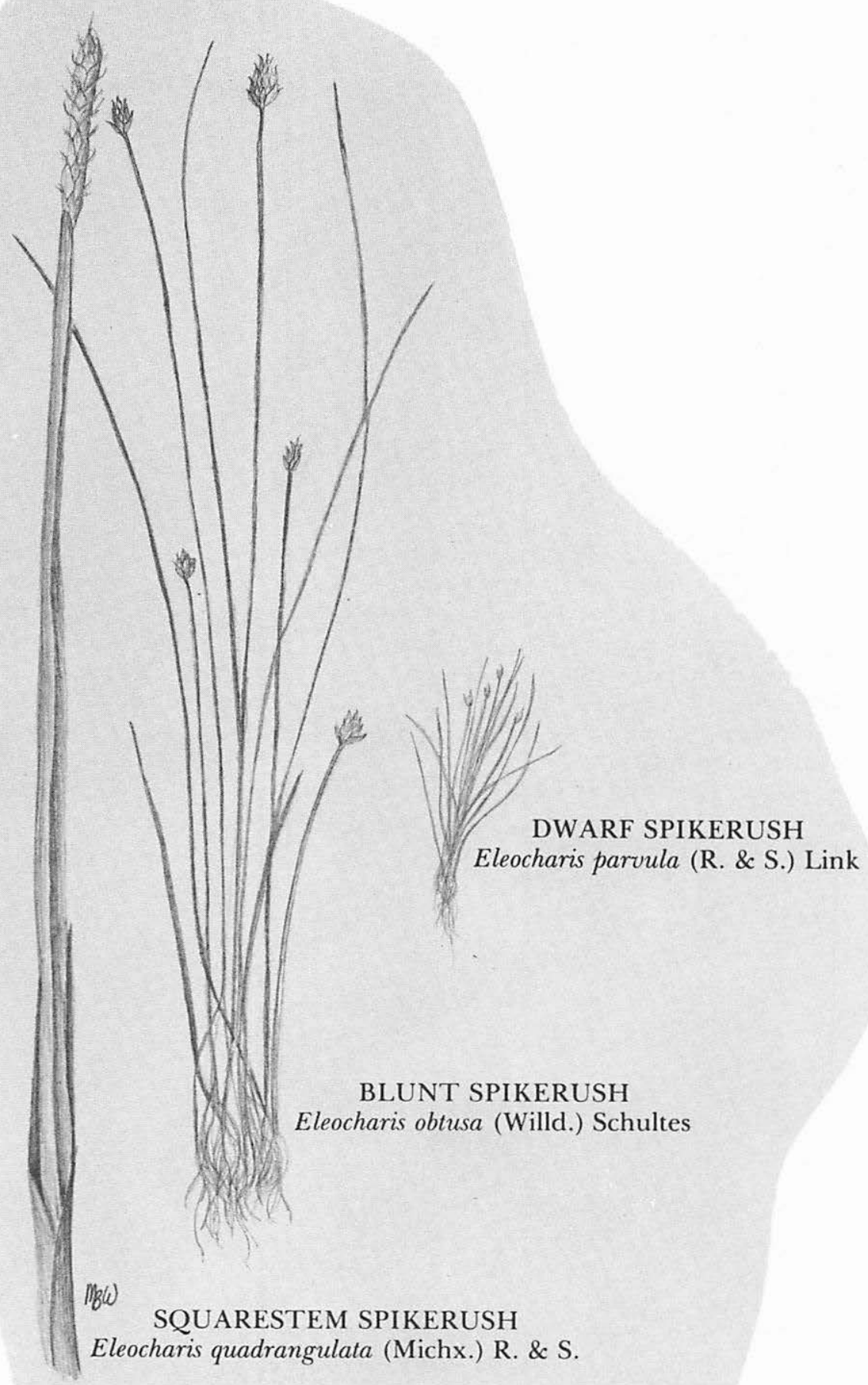




\section{SPIKE RUSHES}

\section{SQUARESTEM SPIKERUSH}

Eleocharis quadrangulata (Michx.) R. \& S.

DWARF SPIKERUSH

Eleocharis paroula (R. \& S.) Link.

\section{BLUNT SPIKERUSH}

Eleocharis obtusa (Willd.) Schultes

The spikerushes are not actually rushes, but belong to the sedge family (Cyperaceae). Spikerushes are leafless with a terminal flowering or fruiting head. There are several different species of spikerushes found in Virginia's marshes. The three species illustrated and described here are typical of those found in these habitats. They are restricted to freshwater marshes except for the Dwarf Spikerush, an occasional plant in brackish marshes.

The Squarestem Spikerush is the largest of the spikerushes. The stem is usually quadrangular or triangular in cross-section and will obtain a height of 4 or 5 feet. The spike is cylindrical and elongated.

Dwarf Spikerush is the smallest of the spikerushes, rarely over 2 inches high. This plant is only occasionally found in brackish marshes, where it is quite inconspicuous.

Blunt Spikerush is a rather medium-sized sedge, (1-2 feet) with a terminal cone-like seed head. This species is often found in freshwater marshes.

The seeds and stems of most species are eaten by waterfowl and muskrats. 


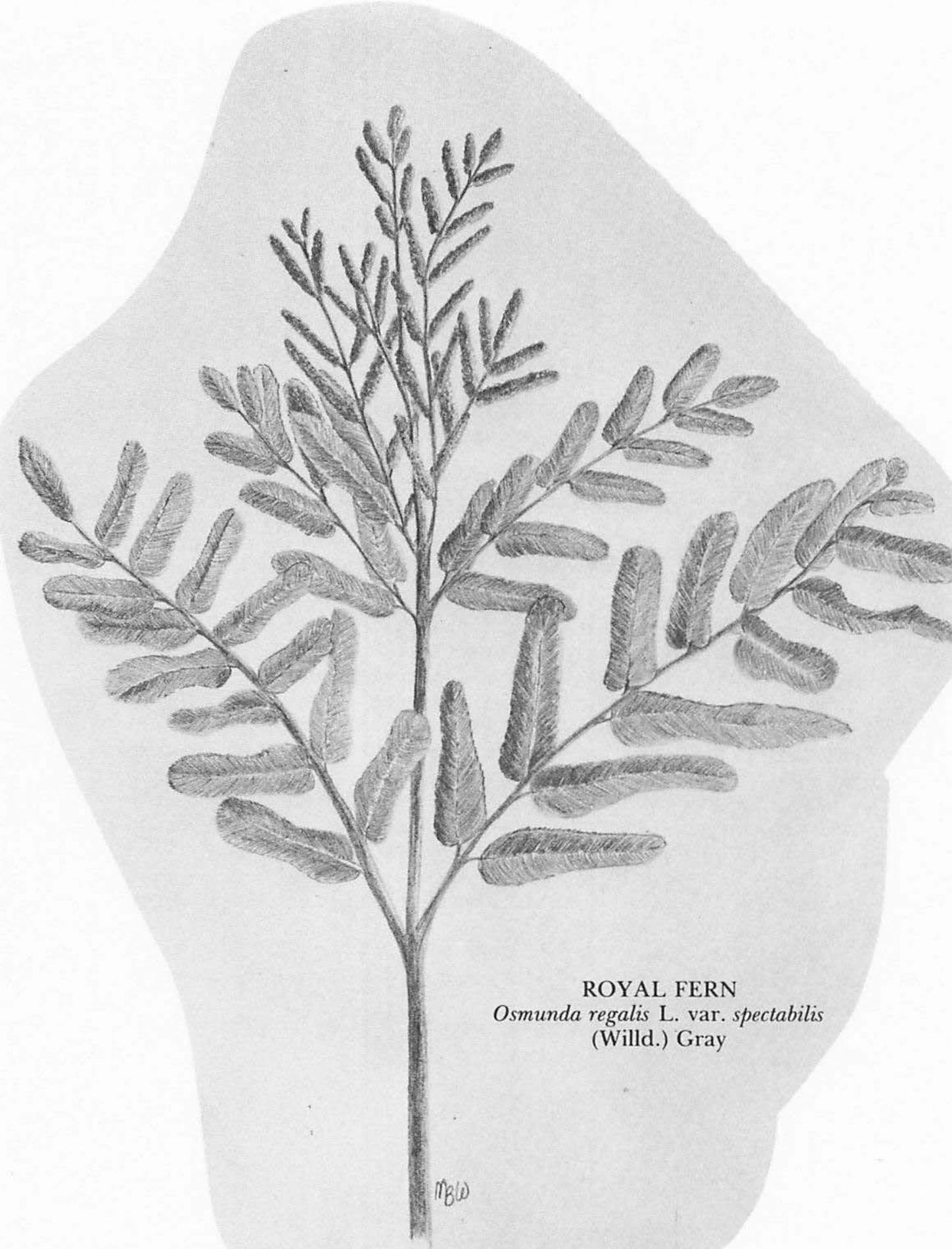


ROYAL FERN

Osmunda regalis $\mathrm{L}$. var. spectabilis

(Willd.) Gray

Royal Fern is one of the most common ferns in tidal freshwater marshes. It is a tall fern, often obtaining a height of 5 feet or more, with spore-forming leaflets (pinnae) at the apex of the plant. The stout, erect rhizomes of this fern are covered with persistent leaf stalks from previous years. Colonies of Royal Fern may exist for centuries because of the enduring rhizomes.

Royal Fern is likely to be found in the higher, hummocky areas in freshwater marshes and is often associated with the shrubs Button Bush, Swamp Rose and Silky Dogwood.

Other ferns such as Sensitive Fern, Netted Chain Fern and Virginia Chain Fern are also likely to be found in freshwater marshes. 


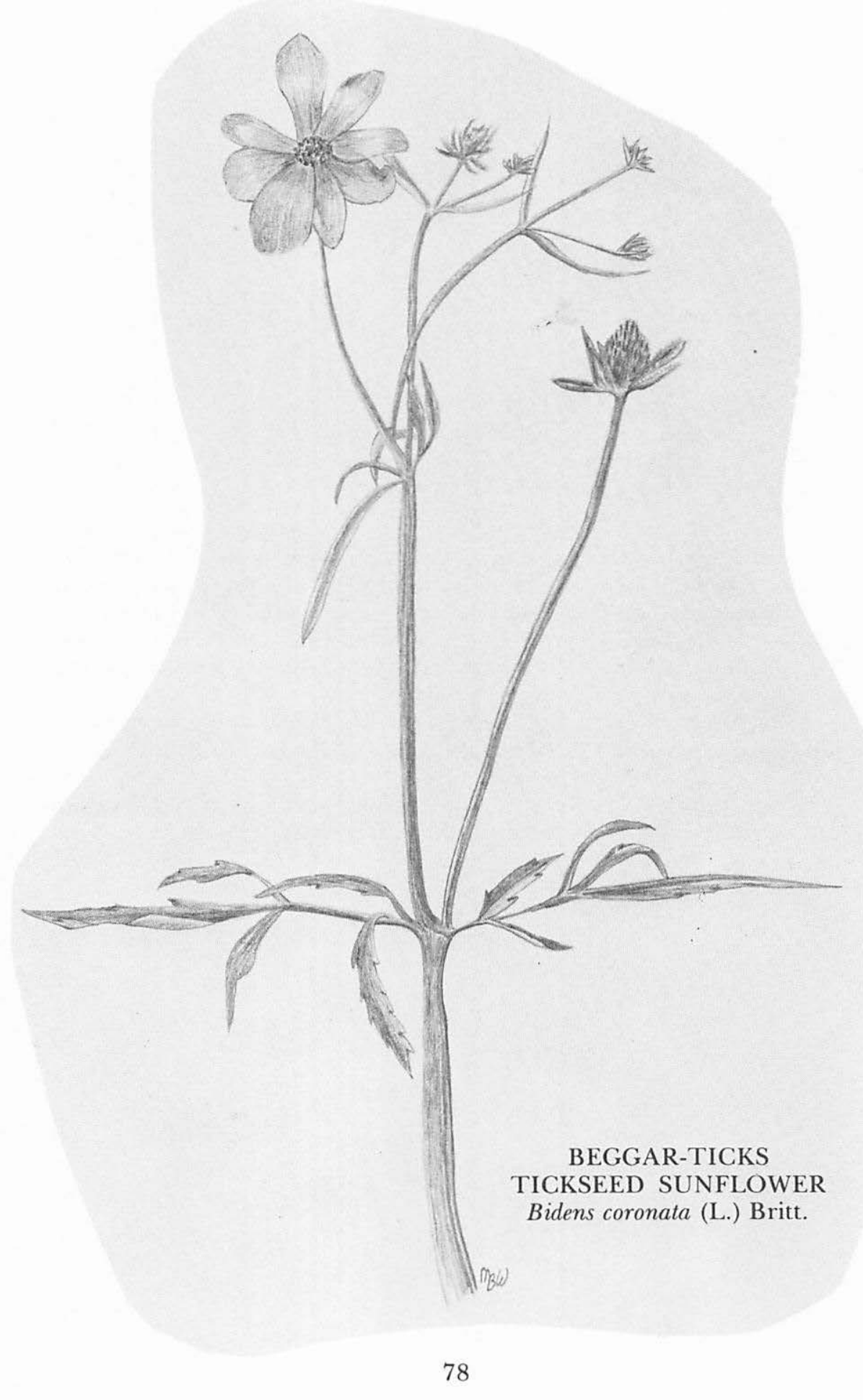




\section{BEGGAR-TICKS \\ TICKSEED SUNFLOWER \\ Bidens coronata (L.) Britt.}

In late summer or early fall many freshwater tidal marshes are aglow with brilliant daisy-like yellow blooms of Beggar's Ticks. Throughout the spring and most of the summer months, however, plants are rather inconspicuous among the other diverse vegetation. The characteristic twin-bristled fruit of Beggar's Ticks or "stick tight" is familiar to most who venture into wet places in the fall.

The species of Bidens featured here appears to be the most common in Virginia's tidewater marshes. Others less common are Bidens laevis and $B$. frondosa. The latter is not as conspicuous in that it does not develop showy yellow blooms.

Occasionally, another yellow blooming plant is found in freshwater marshes, the robust Sneeze-weed or Lowground Weed Helenium autumnal. It's flower heads appear from late August through October. 


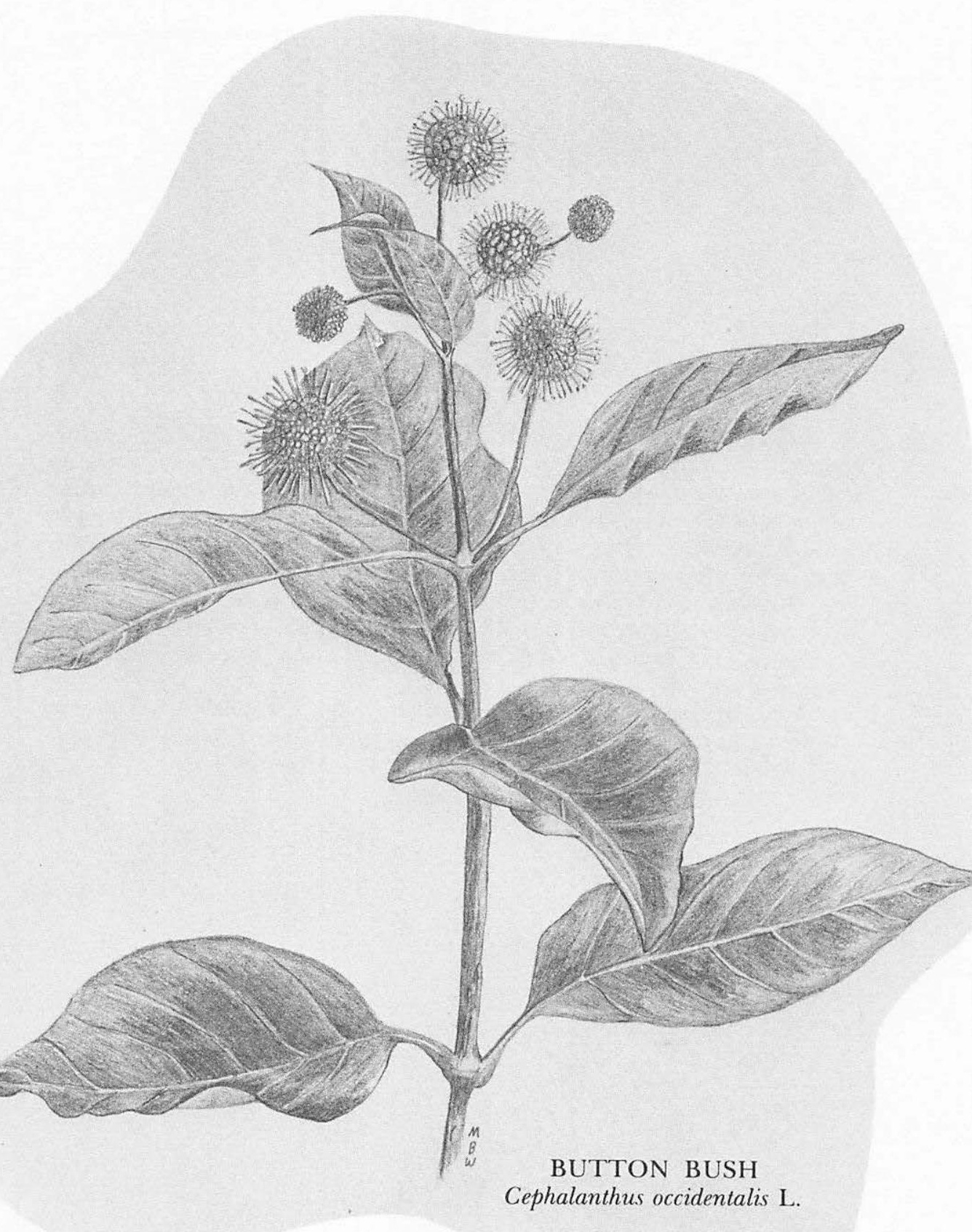




\section{BUTTON BUSH}

\section{Cephalanthus occidentalis $\mathbf{L}$.}

Button Bush is commonly found along the upland margins or on raised hummocks in freshwater marshes. The leaves are leathery-smooth on the upper surface with even margins and are oppositely arranged or whorled (3 or more leaves emerging from one point on the stem). A distinguishing feature is the leaf petioles which are often reddish in color.

From early summer through late fall, a striking white, ball-like infloresence emerges. Delicate elongated stigmas extend from each tublar flower and give the unique flower cluster the appearance of a globular pin cushion. The resulting fruits (nutlets) are compacted into a brownish sphere, also a distinguishing feature during late fall and early winter. The seeds are eaten by Wood Ducks.

Button Bush is often associated with other freshwater wetland shrubs such as: Fetter-bush or Maleberry, Swamp Rose and Silky Dogwood. 


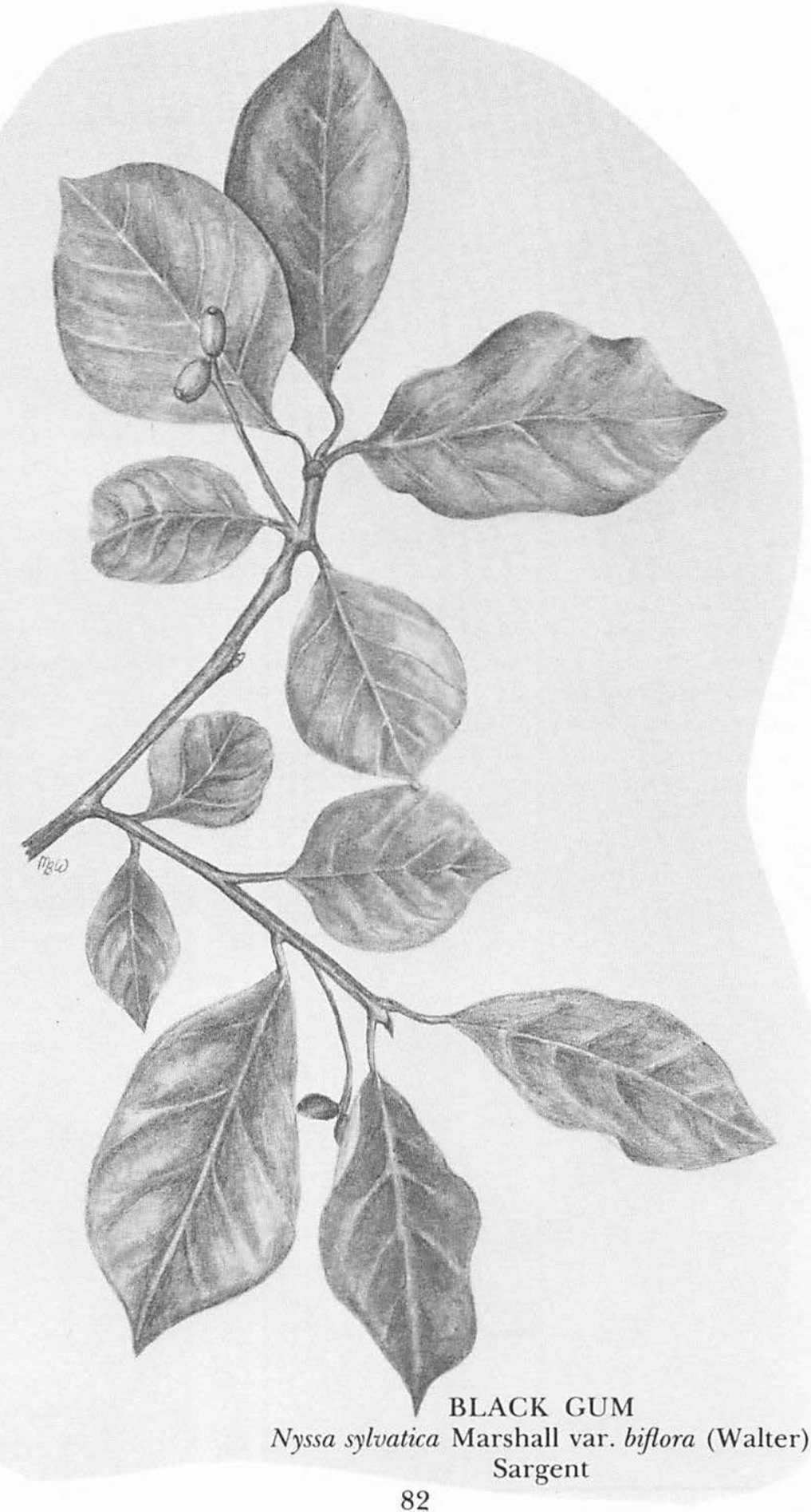




\section{BLACK GUM \\ Nyssa sylvatica Marshall var. biflora (Walter) \\ Sargent (illustrated) \\ TUPELO GUM \\ Nyssa aquatica $\mathrm{L}$.}

The Gums, particularly Black Gum, are commonly found in the tidal freshwater swamps of Virginia. The smooth elliptic leaves are alternately arranged and in autumn change to a brilliant red, usually long before other trees begin to turn. Blue, berrylike fruits (drupes) appear in late summer, usually in two's or three's.

Tupelo Gum is very similar to Black Gum except it has solitary fruits. $N$. aquatica is a southern coastal species. Southeastern Virginia is the northern extension of its range whereas Black Gum is found throughout Virginia as well as much farther north. 


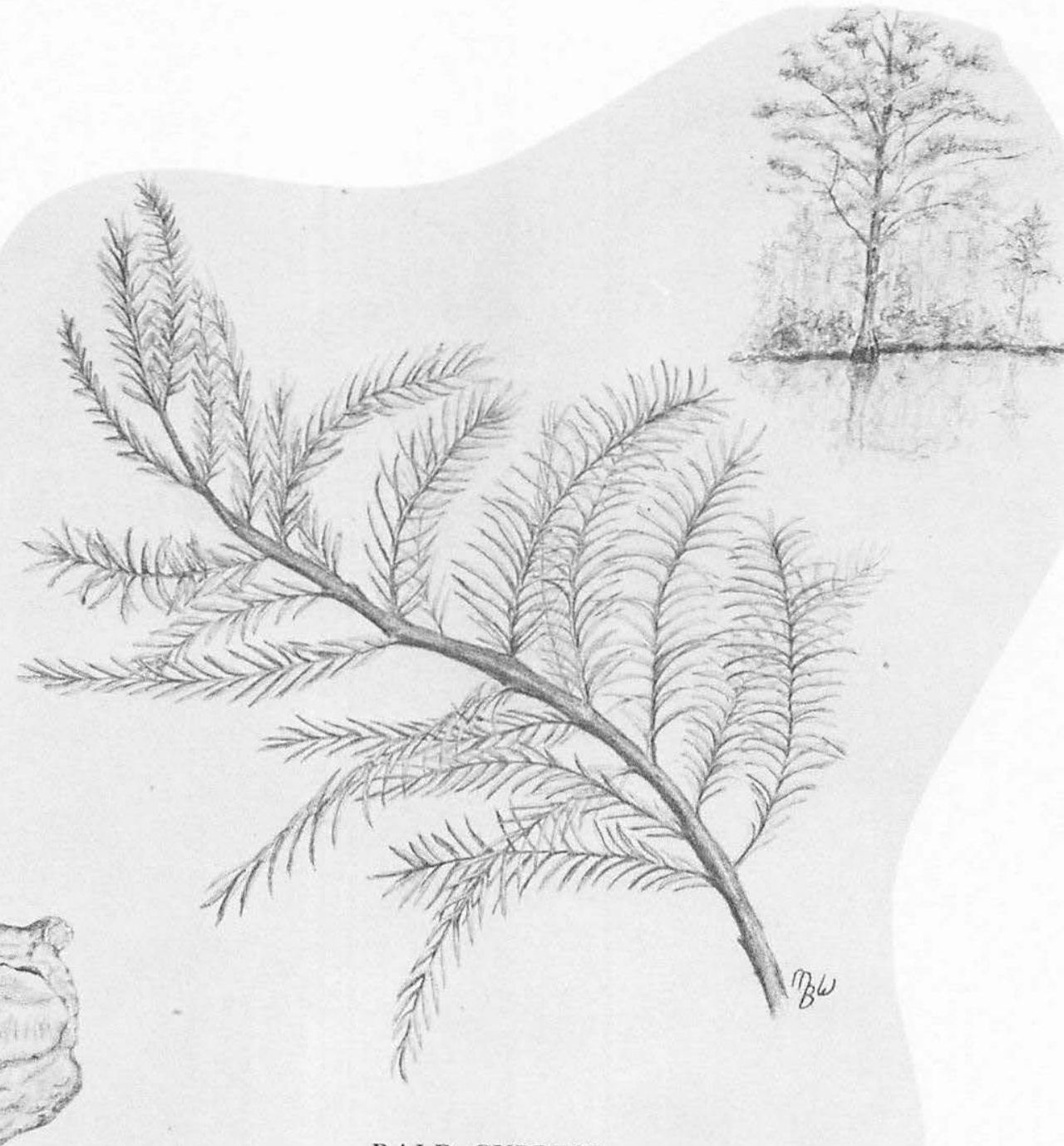

BALD CYPRESS

Taxodium distichum (L.) Richard 


\section{BALD CYPRESS \\ Taxodium distichum (L.) Richard}

Bald Cypress is perhaps the most majestic swamp species in the southeast. In Virginia's tidal swamps this tree is no exception, a towering tree, often dominating in certain areas, especially in the vast wetlands of the Chickahominy River. Bald Cypress is an exception among the conifers in that it is deciduous. It's needles turn a rusty brown in the fall and are entirely lost by winter. The female cones are woody and nearly spherical, shedding winged seeds in October.

"Cypress knees", a common feature of this species, are actually unbranched shoots originating from the roots. The wood of the "knees" is lighter and more porous than the wood of the main trunk and is thought to aid in oxygen exchange for the submerged roots.

The wood is highly valued for its resistance to decay. Because of its durability, it is used for making shingles, posts, railroad ties and boat building. Large tracts of swamps have been logged for Cypress; however many mature stands still remain in isolated areas throughout tidewater Virginia. 